\title{
Enhanced Control of Mercury by Wet Flue Gas Desulfurization Systems - Site 2 Results
}

Technical Note, February 2000

U.S. Department of Energy Contract No.

DE-AC22-95PC95260

Radian International

8501 N. Mopac Boulevard

Austin, Texas 78759

Principal Investigators:
G. Blythe
S. Miller
C. Richardson
K. Searcy

Department of Energy Project Manager

A. Mayne

EPRI Project Manager

R. Rhudy 


\section{DISCLAIMER}

This report was prepared as an account of work sponsored by an agency of the United States Government. Neither the United States Government nor any agency thereof, nor any of their employees, makes any warranty, express or implied, or assumes any legal liability or responsibility for the accuracy, completeness, or usefulness of any information, apparatus, product, or process disclosed, or represents that its use would not infringe privately owned rights. Reference herein to any specific commercial product, process, or service by trade name, trademark, manufacturer, or otherwise does not necessarily constitute or imply its endorsement, recommendation, or favoring by the United States Government or any agency thereof. The views and opinions of authors expressed herein do not necessarily state or reflect thoe of the United States Government or any agency thereof. 


\section{CITATIONS}

This report was prepared by

Radian International

8501 N. Mopac Boulevard

Austin, Texas 78759

Principal Investigators

G. Blythe

S. Miller

C. Richardson

K. Searcy

This report describes research sponsored by EPRI and the Department of Energy.

The report is a corporate document that should be cited in the literature in the following manner:

Enhanced Control of Mercury by Wet flue Gas Desulfurization Systems - Site 2 Results, EPRI, Palo Alto, CA, U.S. Department of Energy, National Energy Technology Laboratory, Pittsburgh, Pennsylvania, February 2000. 


\section{ABSTRACT}

The U.S. Department of Energy and EPRI are co-funding this project to improve the control of mercury emissions from coal-fired power plants equipped with wet flue gas desulfurization (FGD) systems. The project is investigating catalytic oxidation of vapor-phase elemental mercury to a form that is more effectively captured in wet FGD systems. If successfully developed, the process could be applicable to over 90,000 MW of utility generating capacity with existing FGD systems, and to future FGD installations.

Field tests are being conducted to determine whether candidate catalyst materials remain active towards mercury oxidation after extended flue gas exposure. Catalyst life will have a large impact on the cost effectiveness of this potential process. A mobile catalyst test unit is being used to test the activity of four different catalysts for a period of up to six months at each of three utility sites. Catalyst testing at the first site, which fires Texas lignite, was completed in December 1998. Testing at the second test site, which fires a Powder River Basin subbituminous coal, was completed in the fall of 1999, and testing at the third site, which fires a high-sulfur bituminous coal, will begin in early 2000.

This technical note reports results from Site 2; results from Site 1 were reported in a previous technical note. At Site 2, catalysts were tested in several forms, including powders dispersed in sand bed reactors and in more commercially viable forms such as extruded beads and coated honeycomb structures. This technical note presents results from Site 2 for both the sand bed reactors and commercial catalyst forms. Site 3 results are not yet available, but should be available late in the year 2000 .

Field testing is being supported by laboratory tests to screen catalysts for activity at specific flue gas compositions, to investigate catalyst deactivation mechanisms and to investigate methods for regenerating spent catalysts. Laboratory results related to the Site 2 field effort are also included and discussed in this technical note. Preliminary economics, based on Site 2 results, are also presented for a catalyst-based mercury removal process for a plant with an existing FGD system. 


\section{CONTENTS}

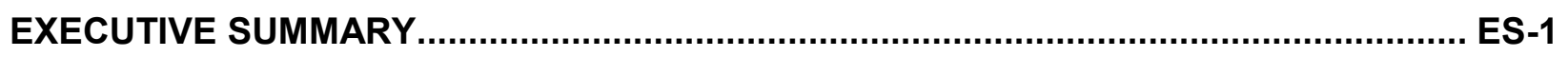

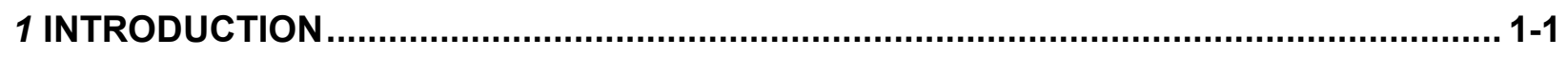

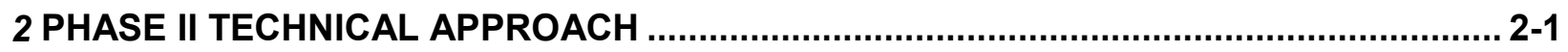

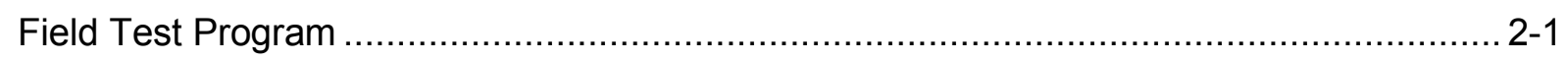

Commercial Catalyst Form Tests ............................................................................ 2-3

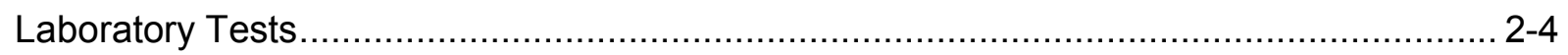

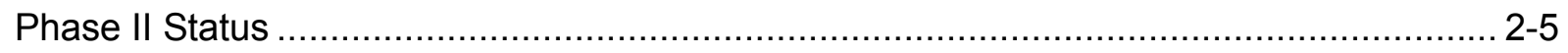

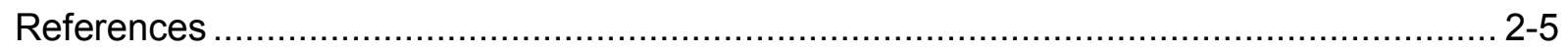

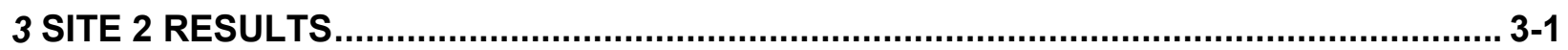

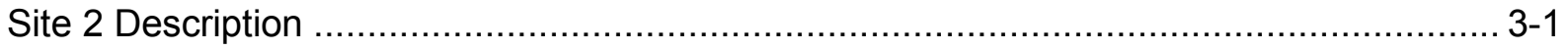

Short-term Catalyst Screening Test Results ………............................................... 3-3

Long-term Test Results ...................................................................................

Commercial Catalyst Form Tests......................................................................... 3-10

Pellet Catalyst Form

Monolith (Honeycomb) Catalyst Structure ……...................................................... 3-11

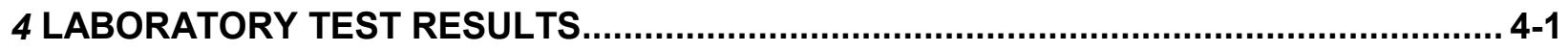

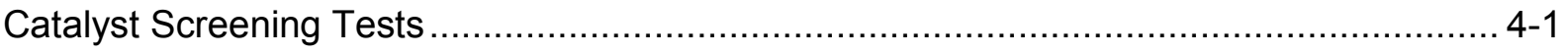

Laboratory Catalyst Deactivation Testing ................................................................. 4-6

Catalyst Regeneration Tests................................................................................ 4-8

Leaching of Acid from Samples Recovered from Site 2 ........................................... 4-9

Regeneration of Catalysts from Site 2 Intermediate-length Tests ................................. 4-10

Regeneration of Catalysts from Site 2 Long-term Test .............................................. 4-12

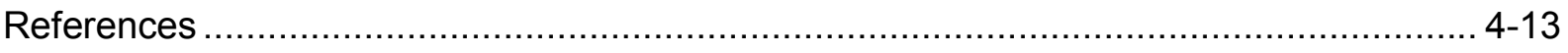


5 PRELIMINARY ECONOMICS FOR A CATALYTIC PROCESS...................................... 5-1

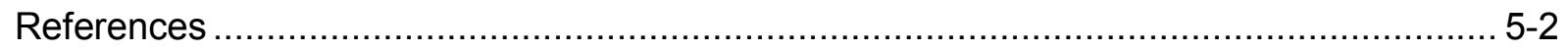

6 CONCLUSIONS.................................................................................................... 6 6

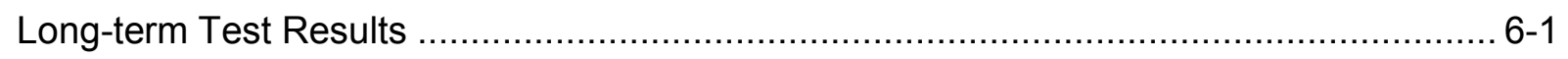

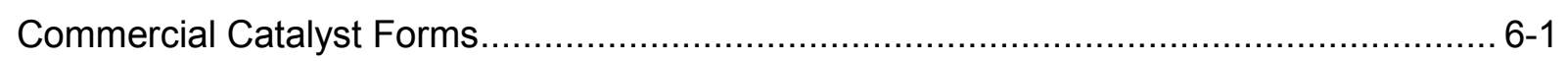

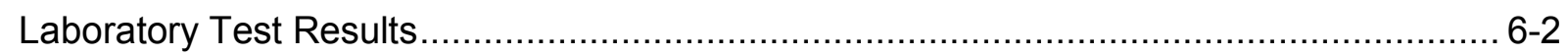

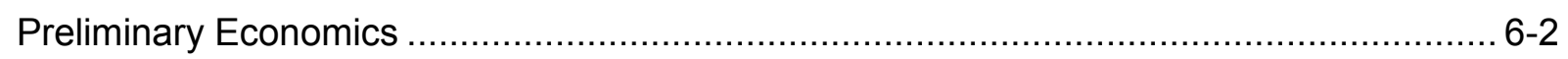

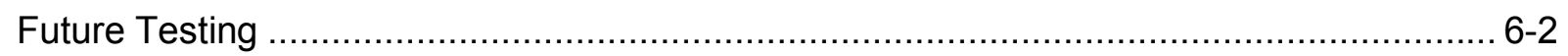

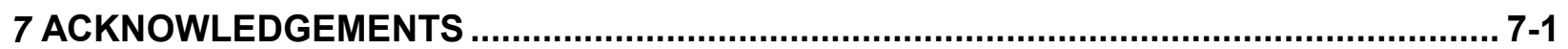




\section{LIST OF FIGURES}

Figure 2-1 Schematic of Field Test Unit and Semi-continuous Mercury Analyzer

Figure 3-1 Activity of Carbon-based Catalysts After Exposure to Site 2 Flue Gas Over a Three-Week Period.

Figure 3-2 Effect of Flue Gas Exposure on Elemental Mercury Oxidation Activity at Site 2 ..... 3-8 Figure 4-1 Acid Leachability for Set 5 Short-term Catalysts at Site 2 .............................. 4-9 


\section{LIST OF TABLES}

Table 3-1 Results of Mercury Balance Calculations for Site 2

Table 3-2 Measured FGD Inlet Flue Gas Conditions at Site 2 .......................................... 3-3

Table 3-3 Method 29 Results for Trace Metal Concentrations for Site 1 and Site 2 ................ 3-4

Table 3-4 Results of Short-term Catalyst Performance Screening Tests at Site 2 .................. 3-5

Table 3-5 Catalyst Configuration for Long-term Testing at Site 2................................... 3-7

Table 3-6 Catalyst Performance at the End of the Long-term Test at Site $2 \ldots \ldots \ldots \ldots \ldots \ldots \ldots \ldots . . . . . .13$

Table 3-7 Area Velocities Tested for Pd \#1 ............................................................... 3-11

Table 3-8 Performance of Pd \#1 on a Honeycomb Structure at Site 2 ............................... 3-12

Table 4-1 Simulated Flue Gas Compositions for Bench-Scale Tests .................................... 4-1

Table 4-2 Comparison of Lab and Field Catalyst Screening Test Results for Site 2 ............... 4-2

Table 4-3 Equilibrium Adsorption Capacity and Mercury Oxidation for Catalysts in Site 2 Simulation Gas with and without $1 \mathrm{ppm} \mathrm{HCl}$......................................................... 4-3

Table 4-4 Effect of $\mathrm{NO}_{x}$ Concentration on the Performance of Carbon \# 1 at $300^{\circ} \mathrm{F}$, Site 2 Simulated Conditions (with $\mathrm{HCl}$ ) ………......................................................... 4-5

Table 4-5 Effect of $\mathrm{NO}_{2}$ Concentration on the Performance of Carbon \# 1 at $300^{\circ} \mathrm{F}$, Site 2 Simulated Conditions (with $\mathrm{HCl}$ ) ....................................................................... 4-6

Table 4-6 Effect of Temperature on Adsorption and Oxidation Performance at Simulated Site 2 Conditions ( $\mathrm{No} \mathrm{HCl}$ )................................................................................. 4-7

Table 4-7 Observed Deactivation Rates for Sand-bed Catalysts in the Laboratory and

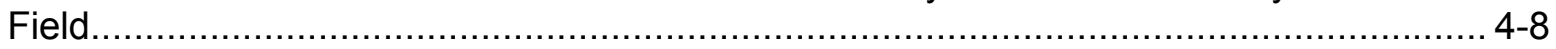

Table 4-8 Performance Comparison of Reagents and Recovered Field Samples ................ 4-11

Table 4-9 Conditions Tested to Regenerate the Carbon \#1 - Bed 1 Sample Recovered from the Site 2 Intermediate-length Screening Tests

Table 4-10 Adsorption and Oxidation of Mercury by Recovered and Regenerated Catalysts.

Table 5-1 Preliminary Cost Estimates for the Catalytic Process for Enhancing Mercury Removal by a Wet FGD System, Compared to Activated Carbon Injection. 


\section{EXECUTIVE SUMMARY}

Field testing at Site 2, fired with a Powder River Basin subbituminous coal, found substantial concentrations of elemental mercury in the flue gas $\left(\sim 8\right.$ to $\left.9 \mu \mathrm{g} / \mathrm{Nm}^{3}\right)$, and relatively low concentrations of $\mathrm{SO}_{2}, \mathrm{SO}_{3}, \mathrm{HCl}$ and $\mathrm{NO}_{\mathrm{X}}$. This was expected based on previous flue gas measurements at sites that fire Powder River Basin coals.

At these flue gas conditions, long-term (five-month) sand bed reactor tests showed that one catalyst, Pd \#1, continued to oxidize $96 \%$ of the inlet elemental mercury. A fly-ash-based catalyst, SBA \#5, continued to achieve $87 \%$ oxidation, and two beds of Carbon \#6 in series achieved $78 \%$ oxidation. The other catalyst, Carbon \#3, had lost virtually all activity towards the oxidation of elemental mercury over this period.

These results identified $\mathrm{Pd} \# 1$ as the most attractive oxidation catalyst for this flue gas with respect to catalyst life. The fly-ash-based SBA \#5 could offer a lower-cost alternative, although a method would need to be developed to prepare the fly-ash-based material in a commercial catalyst form.

Since Pd \#1 represents a conventional, metal-based catalyst that is readily available from catalyst vendors, samples were acquired and tested in two commercially-viable forms: pellet and "honeycomb" configurations. In relatively short-term tests (two to six weeks), the pellet form showed high oxidation activity at area velocities five to ten times that of commercial SCR catalysts, suggesting that relatively small reactors could be employed for a catalytic mercury oxidation process. Results with a honeycomb catalyst showed lower oxidation activity when compared to the pellet form at similar area velocities. The amount of palladium on the honeycomb surface and the rate of diffusion of mercury from the flue gas to its surface are currently being investigated as potential causes of the lower performance.

Laboratory tests indicate that for the gas composition at Site 2, both $\mathrm{HCl}$ and $\mathrm{NO}_{\mathrm{X}}$ play an important role in mercury oxidation, even when present at low concentrations (e.g., 1 ppm for $\mathrm{HCl}$ ). For most materials, the laboratory apparatus proved to be an effective tool at identifying catalyst materials that were active in the actual Site 2 flue gas conditions. However, the effectiveness of accelerated catalyst deactivation tests in the laboratory for predicting long-term catalyst activity in the field remains in question.

Laboratory tests to regenerate spent catalyst materials from the long-term test at Site 2 showed that the catalyst that degraded in activity over the course of the long-term test were readily regenerated with $\mathrm{CO}_{2}$ at elevated temperatures. This result suggests that regeneration should be further investigated as a means for cost-effectively restoring the activity of spent catalysts in future larger-scale application of this technology. 
Preliminary economics have been calculated for the catalytic process applied to a power plant with an existing ESP particulate collector and an FGD system, based on Site 2 results for Pd \#1. These preliminary economics show that the catalytic process could be less costly than carbon injection for achieving 80 to $90 \%$ overall mercury control (relative to mercury levels in the ESP outlet flue gas). The economics are based on using a honeycomb catalyst configuration. The economics for the catalytic process using Pd $\# 1$ as the catalyst are very sensitive to catalyst life and the loading of Pd \#1 required on the honeycomb surface. Future testing should attempt to determine the activity of $\mathrm{Pd} \# 1$ over periods of one year or greater, and should evaluate lowercost materials such as fly-ash-based SBA \#5 in commercial catalyst configurations. 


\section{INTRODUCTION}

The 1990 Clean Air Act Amendments mandated the Environmental Protection Agency to study the health effects caused by hazardous air pollutants (HAPs) from electric utility plants, including a separate study of the effect of mercury emissions. Most HAPs of concern in power plants occur in the particulate phase and are, therefore, removed in particulate control devices. However, mercury, although present in extremely low concentrations, primarily occurs in the vapor phase. Therefore, particulate removal devices are generally not effective at removing mercury from flue gas and alternative removal methods are needed. A number of previous research programs have studied mercury emissions from power plants and methods for reducing these emissions.

The U.S. Department of Energy's National Energy Technology Laboratory (DOE/NETL) is funding this project to investigate a process for improving the ability of existing wet FGD systems to control mercury emissions from coal-fired power plants. The project is being conducted under a cost-sharing PRDA agreement between DOE/NETL, EPRI and Radian International. The proposed process would use a catalyst material to oxidize vapor-phase elemental mercury. Vapor-phase mercury generally exists in two forms in utility flue gas - as elemental mercury and as water soluble, oxidized mercury (the predominant form is believed to be $\mathrm{HgCl}_{2}$ ). Previous results have shown that wet scrubbers effectively remove oxidized mercury from the gas but are ineffective at removing elemental mercury. Since elemental mercury is present in most flue gas streams and is the predominant form in some, this process can potentially improve overall mercury removal in wet scrubbers by converting the elemental mercury to a form that is more readily scrubbed.

This project is being conducted in two phases of a Mega-PRDA test program. During Phase I, several catalyst materials were identified in the laboratory as being able to oxidize elemental mercury. This ability was confirmed in pilot-scale tests and in short-term, slipstream field tests. Pilot tests also confirmed the removal of catalytically-oxidized mercury across a wet FGD system. Phase II began in April 1998, and is investigating catalyst life by exposing catalyst materials to flue gas for an extended period of time at three coal-fired power plants. This testing will be used to predict required catalyst quantities and catalyst life for future full-scale application of the technology.

Section 2 of this technical note describes the technical approach for Phase II and Section 3 presents Phase II results from the second of three planned sites. In Section 4, the results of related laboratory testing are presented, and results from a preliminary economic evaluation of the proposed catalytic process are presented in Section 5. A summary of the Site 2 results is made in Section 6, and a brief acknowledgement is made in Section 7. 


\section{PHASE II TECHNICAL APPROACH}

Based on promising Phase I results, DOE/NETL funded a Phase II effort, which includes:

- Evaluate the ability of catalyst materials to oxidize elemental mercury at three full-scale sites;

- Estimate the life of these catalyst materials in various flue gas streams; and

- Estimate the amount of catalyst required to achieve at least $70 \%$ oxidation of the elemental mercury in these flue gas streams.

Phase II testing is addressing two critical issues - the life of the catalysts (i.e., how long will the catalysts oxidize mercury?) and the applicability of the process for the U.S. electric utility industry (i.e., are there coals/plants for which the catalysts work more or less effectively?). These issues are being addressed by conducting long-term catalyst tests at three full-scale utility sites. Catalyst oxidation efficiency and life will ultimately affect the design of any subsequent commercial process and its economics. Also included in Phase II are field tests of "advanced" or commercial catalyst forms, and laboratory related laboratory testing. Each form of testing is described below.

\section{Field Test Program}

Figure 2-1 illustrates the catalyst test unit, which was designed to expose catalyst materials to a slipstream of flue gas from a coal-fired boiler for an extended period. The test unit consists of a heated box that is mounted directly to a flue gas duct, and is small enough to be moved from site to site. Flue gas is continuously drawn from the duct through a heated glass probe and passes through a quartz filter before contacting the catalyst beds. Although in future full-scale systems, the catalyst would be exposed to fly ash remaining in the flue gas downstream of the particulate control device, residual fly ash is removed in the test unit to prevent plugging of the sand beds. A commercial catalyst configuration (e.g., a honeycomb) would be designed to avoid plugging with ash.

After the filter, the flue gas flows through three parallel catalyst test cells. Each test cell contains two packed beds of catalyst material. Catalyst bed temperatures are controlled by adjusting temperatures in the heated box. The gas flow rate through each test cell is continuously monitored, and gas flow rates are adjusted with manual valves. After flowing through the cells, the flue gas passes through a condenser to remove moisture then to sample pumps. At the normal flue gas flow rate, the superficial gas velocity through a test cell is about $18 \mathrm{ft} / \mathrm{min}(5.5 \mathrm{~m} / \mathrm{min})$, which is similar to the gas velocity through a fabric filter in the EPRI COHPAC configuration (i.e., a pulse-jet fabric filter installed downstream of an ESP). 


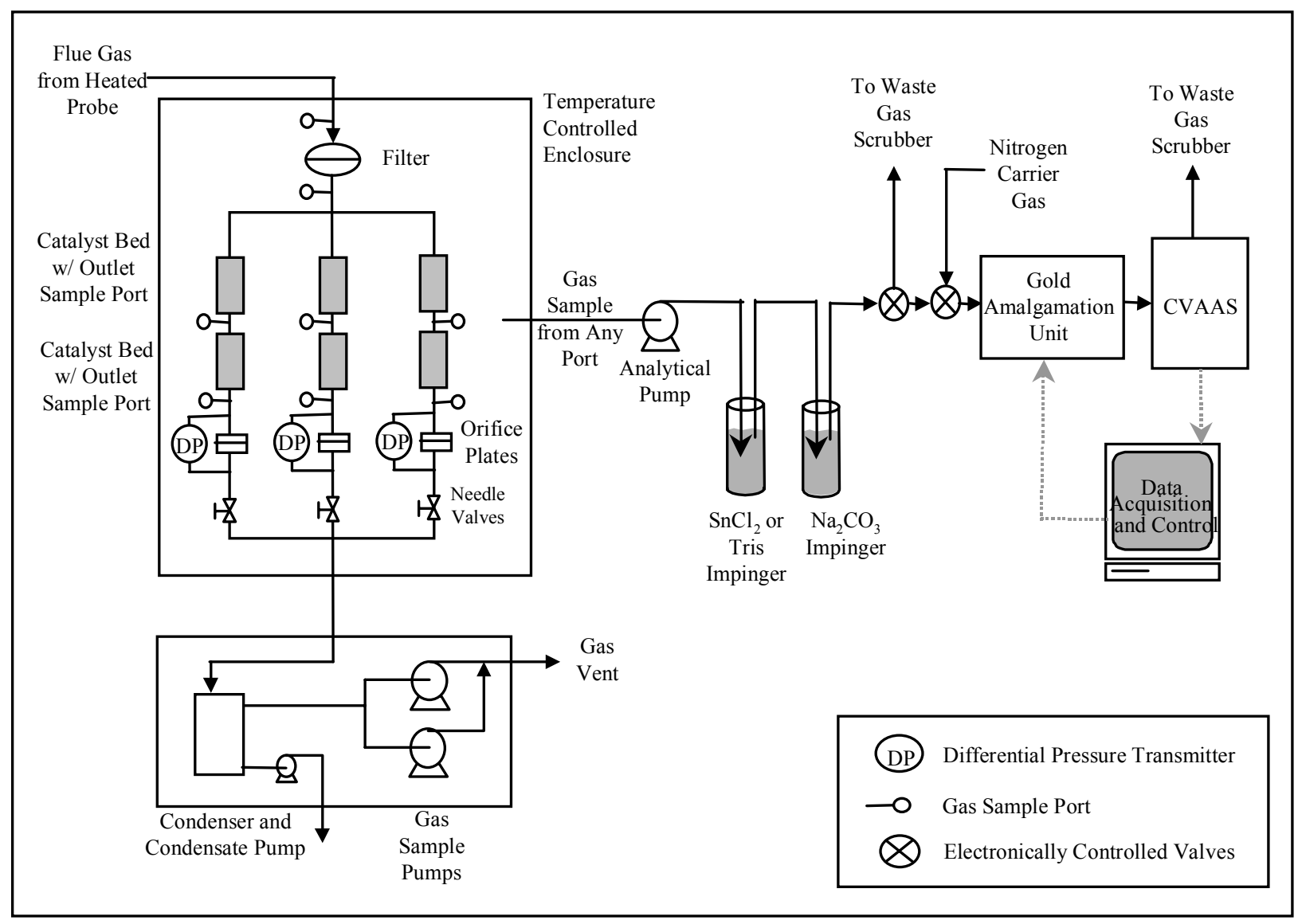

Figure 2-1

Schematic of Field Test Unit and Semi-continuous Mercury Analyzer

There are two catalyst beds in series in each of the three test cells, so up to six different catalyst materials can potentially be tested simultaneously. However, one bed typically contains a sand bed "blank," and another cell typically has two beds containing the same catalyst material in series, to provide oxidation data at two space velocities (i.e., different ratios of gas flow rate to catalyst volume). Consequently, only four different catalyst materials are typically tested at once.

The catalyst materials in the test cells are diluted with sand. The sand improves gas flow distribution by providing a thicker bed and greater gas pressure drop. Test ports are located at the outlet of each catalyst bed and at the inlet and outlet of the quartz filter. Mercury samples can be collected upstream and downstream of all catalyst beds. By measuring the change in elemental mercury concentration across each bed, the mercury oxidation across each can be determined.

Mercury measurements are made using a semi-continuous mercury analyzer developed for EPRI. As shown in Figure 1, flue gas is pulled from the catalyst test unit at about $1 \mathrm{~L} / \mathrm{min}$ through a Teflon ${ }^{\circledR}$-lined pump and passes through a series of impingers. To measure total mercury in the flue gas, the impinger solutions contain stannous chloride $\left(\mathrm{SnCl}_{2}\right)$ followed by a sodium carbonate $\left(\mathrm{Na}_{2} \mathrm{CO}_{3}\right)$ buffer. The $\mathrm{SnCl}_{2}$ solution reduces all flue gas mercury species to elemental 
mercury. The $\mathrm{Na}_{2} \mathrm{CO}_{3}$ solution removes acid gases, thus protecting the downstream, analytical gold surface. Gas exiting the impingers flows through a gold amalgamation column where mercury in the gas is adsorbed. After concentrating mercury onto the gold for a fixed period of time (typically 10 minutes), the mercury is thermally desorbed $\left(>700^{\circ} \mathrm{C}\right)$ from the column into a nitrogen purge stream that flows to a cold-vapor atomic absorption spectrophotometer (CVAAS) for analysis. The flue gas total mercury concentration is measured semi-continuously with a 10minute sample time followed by a 10-minute analysis period.

To measure elemental mercury in the flue gas, the $\mathrm{SnCl}_{2}$ impinger is replaced with one containing tris(hydroxymethyl)aminomethane (Tris) solution. The Tris solution has been shown to capture oxidized mercury while allowing elemental mercury to pass through without being altered ${ }^{1}$. Mercury passing through the Tris solution is analyzed as described above and assumed to represent the elemental mercury content in the gas sampled. The difference between the total mercury concentration (stannous chloride impinger train) and elemental mercury concentration (Tris impinger train) is taken as the oxidized mercury concentration. The analyzer results have been confirmed at each site by performing manual sampling by the draft Ontario Hydro method.

The most promising catalyst materials are being tested for up to six months at each of three utility power plants. At each site, an initial set of short-term screening tests is conducted to determine the most active catalysts for that site and to allow comparing the performance of several catalyst materials from site to site. Each screening test is run for two to four days, to allow the catalysts to approach mercury adsorption equilibrium before measuring oxidation performance. Based on the screening test results, four catalyst materials are selected for continuous long-term (five- to six-month) flue gas testing at each site. Periodic performance measurements are taken to determine if oxidation has changed with time. Between performance measurements, the test unit operating conditions are monitored remotely using mobile communications. This approach is being used to measure catalyst life for four catalyst materials at three coal-fired facilities.

The test sites are being chosen to provide a range of flue gas compositions and will correspond with the three solid fossil fuels used for power generation in the U.S.: bituminous coal, subbituminous coal, and lignite. Of the installed FGD capacity in the U.S., about $48 \%$ (on a megawatt basis) is on power plants that fire bituminous coal, $40 \%$ on plants that fire subbituminous coal, and $12 \%$ on plants that fire lignite.

Testing has been completed at the first site, a power plant that fires a medium-sulfur Texas lignite, and at the second site, which fires a low-sulfur Powder River Basin subbituminous coal. The third site has not been selected, but will fire a high-sulfur bituminous coal.

\section{Commercial Catalyst Form Tests}

During the long-term testing of catalyst sand beds at Site 2, additional tests were conducted to evaluate the activity of catalysts in commercially viable configurations rather than as finely ground powder dispersed in sand. Such configurations could include honeycomb supports [such as those used in flue gas $\mathrm{NO}_{\mathrm{X}}$ selective catalytic reduction $\left.(\mathrm{SCR})\right]$, pellets, and others. The 
objective of these tests has been to evaluate promising catalysts identified in the long-term tests in commercially viable configurations.

These tests were conducted in an apparatus operated in parallel with the long-term field test unit described above. The commercial catalyst form test apparatus drew flue gas from a quartz-lined probe installed in a port next to that of the long-term field test unit. Flue gas was drawn through heated Teflon ${ }^{\circledR}$ sample lines to one or more Teflon ${ }^{\circledR}$ catalyst holders placed in a temperaturecontrolled, heated box. From the catalyst holder(s), the treated flue gas was pulled through a vacuum pump that discharged the small amount of flue gas to the atmosphere. Flue gas flow rates were measured with a calibrated rotameter on a periodic basis. Mercury concentrations were measured upstream and downstream of each catalyst holder using the field analytical instrument described above. These analyses were conducted when the analyzer was not being used to measure mercury concentrations for the long-term field test.

The catalyst holders contained either 5-mm-diameter extruded beads of catalyst material or 5/8inch (1.6-cm) diameter "cores" of catalyst material on a monolithic (honeycomb) support. These catalyst forms were tested for time periods ranging from two to six weeks.

The testing was focused on flue gas flow rates that would correspond with commercially viable catalyst reactor sizes. If we assume that mercury oxidation occurs primarily on the external surfaces of the catalyst materials (i.e., not in the pores), a design term called area velocity probably represents the best parameter for scaling small-scale reactor results to a commercial catalyst bed design. Area velocity is calculated as the flue gas flow rate at standard conditions divided by the catalyst material's geometric (external) surface area. SCR catalysts typically operate at area velocities ranging from 15 to 30 standard $\mathrm{ft} / \mathrm{hr}(4.3$ to $8.7 \mathrm{Nm} / \mathrm{hr}$ ). If mercury catalysts can be proven effective at similar or higher area velocities, it is likely that honeycomb support structures could be utilized in a reactor of a commercially viable size. The actual area velocities tested for mercury catalysts at Site 2 ranged from 110 to 860 standard $\mathrm{ft} / \mathrm{hr}$ (32 to 250 $\mathrm{Nm} / \mathrm{hr}$ ) for the bead catalyst form, and from approximately 105 to 240 standard $\mathrm{ft} / \mathrm{hr}$ (30 to 69 $\mathrm{Nm} / \mathrm{hr}$ ) for the monolith.

\section{Laboratory Tests}

Laboratory tests are also being conducted to support the field tests. Typically, a simulated flue gas containing elemental mercury flows across a fixed-bed reactor containing catalyst material. The gas exiting the bed is analyzed semi-continuously by the technique described above to determine the fraction of inlet elemental mercury oxidized across the bed. Mercury speciation across the catalyst bed is determined after adsorption equilibrium is established.

The simulated flue gas is prepared from reagent gases using calibrated flow meters. Elemental mercury is added by passing nitrogen carrier gas across a diffusion cell that contains an elemental mercury permeation tube. The amount of diffused mercury is controlled with the flow of nitrogen and the temperature of the diffusion cell. The mercury-containing nitrogen is then mixed with other flue gas components $\left(\mathrm{SO}_{2}, \mathrm{HCl}, \mathrm{NO}_{\mathrm{x}}, \mathrm{O}_{2}, \mathrm{CO}_{2}\right.$, and $\left.\mathrm{H}_{2} \mathrm{O}\right)$ at constant temperature before the gas enters the reactor. 
The fixed-bed reactor is a temperature-controlled, vertical Pyrex column that contains a mixture of the catalyst material and sand. The gas rate is typically about $1.4 \mathrm{~L} / \mathrm{min}$ at $300^{\circ} \mathrm{F}\left(149^{\circ} \mathrm{C}\right)$, which results in a superficial gas velocity through the bed of about $30 \mathrm{ft} / \mathrm{min}(9.1 \mathrm{~m} / \mathrm{min})$.

The bench-scale unit is used to simulate flue gas conditions at each full-scale test site prior to testing in the field, to obtain information about the expected effects of flue gas composition on oxidation. The bench-scale unit is also being used to investigate the regeneration of spent catalysts. Spent catalysts are regenerated by exposure to various atmospheres at elevated temperatures, then tested for mercury oxidation activity in simulated flue gas. Other tests are run on the bench-scale unit in an effort to develop a better understanding of mercury oxidation and catalyst deactivation mechanisms.

\section{Phase II Status}

Phase II results to date include completed long-term test series at Sites 1 and 2, screening tests for the activity of commercial catalyst forms at Site 2, and laboratory-scale catalyst screening and regeneration tests. Site 1 results have been reported previously ${ }^{2,3,4}$, and are not repeated here. This technical note is focused on results from Site 2 and from related laboratory tests.

\section{References}

1. Carey, T.R., et al. "Effect of Mercury Speciation on Removal Across Wet FGD Processes." Presented at the AIChE Spring National Meeting, Session 47, New Orleans, LA, February 25-29, 1996.

2. Blythe,G.M., et. al. "Enhanced Control of Mercury by Wet FGD Systems." Presented at the AWMA 92 ${ }^{\text {nd }}$ Annual Meeting, St. Louis, MO, June 1999.

3. Richardson, Dr. Carl F., et al. "Enhanced Control of Mercury by Wet FGD Systems." Presented at the EPRI-DOE-EPA Combined Utility Air Pollution Control Symposium: The MEGA Symposium, Atlanta, GA, August 16-20, 1999.

4. Enhanced Control of Mercury by Wet Flue Gas Desulfurization Systems - Site 1 Results, EPRI, Palo Alto, CA, and U.S. Department of Energy, Federal Energy Technology Center, Pittsburgh, PA, 1999, TE-113397. 


\section{3 \\ SITE 2 RESULTS}

\section{Site 2 Description}

Site 2 is a moderately large (400-600 MW) tangentially-fired unit that fires a blend of Wyoming, Powder River Basin subbituminous coals. It has an ESP for particulate control and a wet limestone FGD system. Site 2 was selected because Wyoming coal is fired by the greatest number of megawatts of generating capacity among FGD-equipped power plants that fire subbituminous coal.

Flue gas mercury concentration measurements were made at Site 2 in December 1998, using the draft Ontario Hydro method. Simultaneous measurements were made in triplicate downstream of one of the unit's induced draft fans (FGD inlet) and downstream of one FGD module. The results showed an average total mercury concentration of $12.0 \mu \mathrm{g} \mathrm{Hg} / \mathrm{Nm}^{3}$ and an average gas phase elemental mercury concentration of $8.8 \mu \mathrm{g} \mathrm{Hg} / \mathrm{Nm}^{3}$ in the flue gas upstream of the FGD system. These values correspond to an average mercury oxidation percentage of $27 \%$ at the FGD inlet.

Samples of the coal fired at Site 2 were collected during each sampling run. The coal mercury content averaged $123 \mathrm{ppb}$ (dry basis) in these three samples. Material balance calculations were conducted to compare the mercury in the coal fired versus that measured in the flue gas, and showed a very good average closure of $98 \%$, with individual sample run closures of $65 \%, 110 \%$ and $121 \%$. This material balance is summarized in Table 3-1.

The flue gas sample runs at the FGD outlet location indicated an average total mercury concentration of $9.3 \mu \mathrm{g} \mathrm{Hg} / \mathrm{Nm}^{3}$ and an average gas phase elemental mercury concentration of $9.0 \mu \mathrm{g} \mathrm{Hg} / \mathrm{Nm}^{3}$. As expected based on results from other sites, the FGD system at Site 2 was observed to remove a high percentage $(93 \%)$ of the oxidized mercury in the flue gas at the FGD inlet, and essentially none of the elemental mercury. The overall mercury removal across the FGD system averaged $23 \%$.

There was only one problem during the sampling runs that resulted in a concern about data quality. The sampling train failed its post-run leak check after the first run at the FGD inlet location. At first it was thought that the leak developed when the sampling probe was removed from the duct at the end of the run. However, higher flue gas oxygen content and lower flue gas mercury concentrations measured for this run compared to those of the other two runs at this location suggest that the leak occurred while the sample was being collected. The first run also showed the poorest closure in the coal mercury material balance calculations mentioned above (65\%). 
Table 3-1

Results of Mercury Balance Calculations for Site 2

\begin{tabular}{|l|c|}
\hline \multicolumn{1}{|c|}{ Parameter } & December 1998 Values \\
\hline Coal mercury content, $\mathrm{mg} / \mathrm{kg}$ & 0.094 \\
\hline Amount of coal fired, tons $/ \mathrm{hr}(\mathrm{kg} / \mathrm{hr})^{*}$ & $197\left(179 \times 10^{3}\right)$ \\
\hline Mercury in coal fired, Ib/hr $(\mathrm{g} / \mathrm{hr})$ & $0.0371(16.8)$ \\
\hline Total mercury concentration in ESP outlet flue gas, $\mu \mathrm{g} / \mathrm{Nm}^{3}$ & 12.0 \\
\hline Flue gas flow rate at ESP outlet, dscfm $\left(\mathrm{Nm}^{3} / \mathrm{s}\right)^{*}$ & $855,000(404)$ \\
\hline Total mercury in flue gas, lb/hr $(\mathrm{g} / \mathrm{hr})$ & $0.0358(16.3)$ \\
\hline Mercury concentration in fly ash, $\mathrm{mg} / \mathrm{kg}$ & 0.020 \\
\hline Fly ash collection rate, tons/hr $(\mathrm{kg} / \mathrm{hr})^{*}$ & $8.9(8100)$ \\
\hline Mercury in fly ash collected, lb/hr $(\mathrm{g} / \mathrm{hr})$ & $0.0004(0.2)$ \\
\hline Mercury in bottom ash, lb/hr $(\mathrm{g} / \mathrm{hr})$ & $0($ assumed) (0.0) \\
\hline Total mercury accounted for in flue gas and fly ash, lb/hr (g/hr) & $0.0362(16.4)$ \\
\hline Mercury material balance closure, \% of coal mercury accounted for & 98 \\
\hline
\end{tabular}

*By combustion calculation

These results confirmed that this unit would be a suitable host site for mercury oxidation catalyst testing, as the flue gas has an adequate elemental mercury concentration to support such testing.

Subsequent flue gas analyses were conducted in March, 1999. Flue gas mercury concentrations were measured by Method 29T, and flue gas $\mathrm{HCl}$ and chlorine $\left(\mathrm{Cl}_{2}\right)$ analyses were conducted by Method 26A. These results are shown in the flue gas compositions presented in Table 3-2. At this later date, Method 29T showed total mercury concentrations at the FGD inlet averaging about $13 \mu \mathrm{g} / \mathrm{Nm}^{3}$, and elemental mercury concentrations averaging about $8 \mu \mathrm{g} / \mathrm{Nm}^{3}$. The relatively high elemental mercury concentration shown in these analyses confirmed that Site 2 would be a good catalyst test site.

The results showed that the $\mathrm{HCl}$ and $\mathrm{Cl}_{2}$ concentrations at Site 2 were, as expected, quite low (about 1 ppm each). Also shown in Table 3-2 are typical FGD inlet $\mathrm{SO}_{2}$ and $\mathrm{NO}_{\mathrm{X}}$ concentrations as measured by the Site $2 \mathrm{CEM}$ system, and $\mathrm{SO}_{3}$ concentrations that were measured at the FGD inlet location by the Controlled Condensation System method, in November, 1999. These results all show relatively low values, as would be expected for Powder River Basin coal fired in a tangentially-fired boiler.

Also in March 1999, Method 29 was run at the FGD inlet location to measure the concentrations of trace species in the flue gas (other than mercury, mostly associated with the small amount of 
Table 3-2

Measured FGD Inlet Flue Gas Conditions at Site 2

\begin{tabular}{|c|c|}
\hline Flue Gas Parameter & Site 2 - March 1999 \\
\hline FGD Inlet $\left[\mathrm{Hg}^{0}\right]$ & $7.6 \mu \mathrm{g} / \mathrm{Nm}^{3}$ \\
\hline FGD Inlet [Hg total] & $13.4 \mu \mathrm{g} / \mathrm{Nm}^{3}$ \\
\hline $\mathrm{Hg} \%$ Oxidation & $43 \%$ \\
\hline $\mathrm{SO}_{2}$ & $300 \mathrm{ppm}$ (wet basis) \\
\hline $\mathrm{SO}_{3}$ & $<0.2 \mathrm{ppm}$ (dry basis) \\
\hline $\mathrm{HCl}$ & $1.1 \mathrm{ppm}$ (wet basis) \\
\hline $\mathrm{Cl}_{2}$ & $1.2 \mathrm{ppm}$ (wet basis) \\
\hline $\mathrm{NO}_{\mathrm{x}}$ & $160 \mathrm{ppm}$ (wet basis) \\
\hline
\end{tabular}

fly ash remaining in the ESP outlet gas). The total mercury concentration measured by Method 29 in three runs averaged $13.1 \mu \mathrm{g} / \mathrm{Nm}^{3}$, which shows excellent agreement with the average results measured by Method 29T, which were included in Table 3-2. The average measurements by the two methods agreed within $2 \%$. The average concentrations of other metals measured by Method 29 at Site 2 are summarized in Table 3-3. For comparison, concentrations previously measured at Site 1 (Texas lignite-fired) are also shown.

Metals concentrations highlighted in bold are present in concentrations greater than $5 \mathrm{ppb}$ at either site and/or showed substantially different concentrations at the two sites. As expected, the lignite fired at Site 1 resulted in higher concentrations of several metals. In particular, much higher selenium levels were measured in the Site 1 flue gas. The largest differences between the two sites occurred for potassium, sodium, calcium, selenium, and aluminum.

\section{Short-term Catalyst Screening Test Results}

During March 1999, the field test unit was installed at Site 2 and short-term screening tests were conducted to evaluate catalyst performance. Six carbon-based catalysts, one fly-ash-based catalyst, and four metal-based catalysts were screened for mercury oxidation activity in the Site 2 flue gas in short-term (three- to nine-day tests). The catalysts screened for activity in the field were selected on the basis of laboratory tests using simulated Site 2 flue gas. The results of those tests are discussed in a later section. Table 3-4 summarizes the results of the screening tests conducted at Site 2 .

For catalysts where results for two beds are listed, the first result is for the upstream bed, and the second result is for the two beds in series. For catalysts for which only one bed is noted, this catalyst was in the " $2 \mathrm{~b}$ " cell position, downstream of the sand bed "blank." The results for all 
SITE 2 RESULTS

Table 3-3

Method 29 Results for Trace Metal Concentrations for Site 1 and Site 2

\begin{tabular}{|c|c|c|}
\hline \multirow[b]{2}{*}{ Metal Species } & \multicolumn{2}{|c|}{ Concentration (ppb) } \\
\hline & Site 1 & Site 2 \\
\hline Aluminum & 20.24 & 10.22 \\
\hline Antimony & 0.17 & 0.07 \\
\hline Arsenic & ND & 0.01 \\
\hline Barium & 0.09 & 0.08 \\
\hline Beryllium & 0.27 & 0.06 \\
\hline Cadmium & 0.05 & 0.02 \\
\hline Calcium & 40.98 & 15.70 \\
\hline Chromium & 0.19 & 0.12 \\
\hline Cobalt & ND & 0.02 \\
\hline Copper & 0.48 & 0.56 \\
\hline Iron & 9.08 & 8.62 \\
\hline Lead & 0.11 & 0.05 \\
\hline Magnesium & 3.02 & 3.05 \\
\hline Manganese & 0.49 & 2.24 \\
\hline Molybdenum & 0.01 & 0.02 \\
\hline Nickel & 0.41 & 0.17 \\
\hline Potassium & 89.30 & 3.17 \\
\hline Selenium & 26.79 & 2.94 \\
\hline Silver & 0.01 & 0.01 \\
\hline Sodium & 191.31 & 120.24 \\
\hline Strontium & 0.09 & 0.04 \\
\hline Thallium & 4.52 & 0.40 \\
\hline Tin & 0.80 & -0.60 \\
\hline Titanium & 0.64 & 0.16 \\
\hline Vanadium & 0.06 & 0.00 \\
\hline Zinc & 2.09 & 2.30 \\
\hline
\end{tabular}


Table 3-4

Results of Short-term Catalyst Performance Screening Tests at Site 2

\begin{tabular}{|c|c|c|c|c|}
\hline $\begin{array}{c}\text { Sample } \\
\text { Type }\end{array}$ & Sample ID & $\begin{array}{c}\text { Sample } \\
\text { Loading (mg } \\
\text { catalyst) }\end{array}$ & $\begin{array}{c}\text { Mercury } \\
\text { Adsorption } \\
\text { Breakthrough } \\
\text { (\% of inlet } \mathrm{Hg})\end{array}$ & $\begin{array}{c}\text { Elemental } \\
\text { Mercury } \\
\text { Oxidation (\% of } \\
\left.\text { inlet } \mathrm{Hg}^{0}\right)\end{array}$ \\
\hline \multirow[t]{12}{*}{ Carbon } & Carbon \#1 - First Bed & 150 & 95 & 78 \\
\hline & Carbon \#1 - Second Bed & 300 & 98 & 72 \\
\hline & Carbon \#2 - First Bed & 75 & 84 & 0 \\
\hline & Carbon \#2 - Second Bed & 150 & 75 & 32 \\
\hline & Carbon \#2 - Repeat (One Bed) & 75 & 95 & 61 \\
\hline & Carbon \#3 (One Bed) & 150 & 83 & 77 \\
\hline & Carbon \#4 - First Bed & 150 & 84 & 25 \\
\hline & Carbon \#4 - Second Bed & 300 & 100 & 89 \\
\hline & Carbon \#5 - First Bed & 75 & 76 & 0 \\
\hline & Carbon \#5 - Second Bed & 150 & 59 & 93 \\
\hline & Carbon \#6 - First Bed & 150 & 79 & 82 \\
\hline & Carbon \#6 - Second Bed & 300 & 90 & 78 \\
\hline Fly Ash & SBA \#5 & 1125 & 11 & 80 \\
\hline \multirow[t]{6}{*}{ Metal } & Fe \#1 (One Bed) & 3750 & 87 & 29 \\
\hline & Pd \#1 - First Bed & 3750 & 89 & 90 \\
\hline & Pd \#1 - Second Bed & 7500 & 82 & $>90$ \\
\hline & Pd \#2 (One Bed) & 500 & 100 & 95 \\
\hline & Pd \#3 - First Bed & 3750 & 100 & 92 \\
\hline & Pd \#3 - Second Bed & 7500 & 100 & $>92$ \\
\hline
\end{tabular}


catalysts have been corrected to account for any observed adsorption or oxidation across the sand bed blank.

The results in Table 3-4 show that only five of the eleven samples achieved oxidation near or above $90 \%$. Three of these five samples were palladium-based catalysts. The $\mathrm{Pd} \# 1$ catalyst is commercially available, but the $\mathrm{Pd} \# 2$ and $\mathrm{Pd} \# 3$ catalysts tested were chemical reagents in powder form. The relative lifetime before deactivation of these three catalysts was not known. Because it is commercially available, $\mathrm{Pd} \# 1$ was the only palladium-based catalysts selected for the long-term test.

The two carbon-based catalysts that achieved high oxidation, Carbon \#4 and Carbon \#5, demonstrated substantially lower oxidation in the first bed relative to that with both beds. This either indicates inconsistent results between the first bed and second bed measurements for each, or indicates rapid loss of activity of the material in the first bed. Therefore, neither appeared to be an ideal choice for long-term testing. All catalysts screened except Fe \#1 and Carbon \#2 had at least one sample (first or second bed) that demonstrated over $70 \%$ oxidation.

For this reason, an intermediate-length test was conducted with three of the carbon-based catalysts. As mentioned previously, the short-term catalyst screening tests described above were conducted in March 99. The Site 2 unit had a scheduled outage coming up in late April, so it was decided to wait to start the long-term test until after the outage. The intermediate-length test with the three carbons was conducted in April prior to the outage. Results from this test are summarized in Figure 3-1.

The longer test period (three weeks) was intended to discern which of three carbon catalysts tested would remain most active and might, therefore, be most likely to remain active over the duration of the subsequent long-term test. Carbon \#5 showed poor activity/life relative to the other carbons and continually lost activity throughout the test. Carbon \#1 and Carbon \#6 both exhibited high initial oxidation followed by some degree of deactivation. Carbon \#1 lost activity more readily than Carbon \#6 indicating that the latter would be a better choice in the Site 2 longterm tests.

\section{Long-term Test Results}

The screening test results described above were used to identify catalysts for long-term testing at this site. The long-term test was started in May 1999, but in June a power outage allowed flue gas moisture and acid gases to condense on the catalyst surfaces. Because it was so early in the test, it was restarted with fresh catalyst material rather than risk adverse effects from this temperature upset. The long-term test at Site 2 was completed in mid-November 1999. At the completion of the long-term test, the catalysts had been exposed to flue gas for approximately 3864 hours.

Table 3-5 summarizes the catalyst materials and loadings tested at Site 2 . Of these, all but Carbon \#3 were also previously tested in long-term tests at Site 1. Carbon \#3 is an experimental carbon derived from Illinois bituminous coal. Carbon \#3 was not one of the three tested in the 


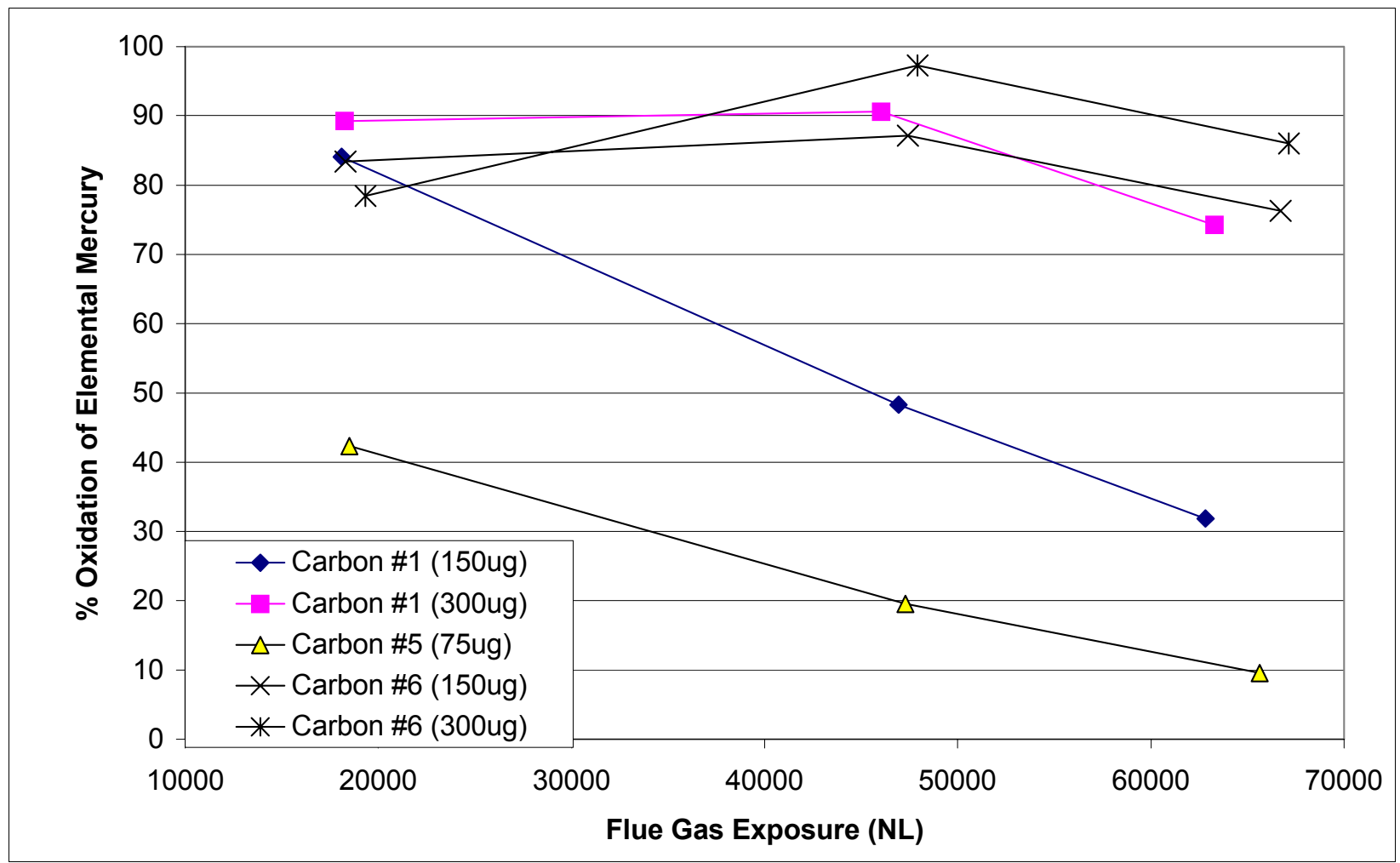

Figure 3-1

Activity of Carbon-based Catalysts After Exposure to Site 2 Flue Gas Over a three-week Period

Table 3-5

Catalyst Configuration for Long-term Testing at Site 2

\begin{tabular}{|c|c|c|c|}
\hline Bed Position & Test Cell \#1 & Test Cell \#2 & Test Cell \#3 \\
\hline Packed Bed \#1 & $\begin{array}{c}0.25 \mathrm{~g} \text { Carbon \#6 in } 75 \mathrm{~g} \\
\text { sand }\end{array}$ & $75 \mathrm{~g}$ of sand & $\begin{array}{c}0.25 \mathrm{~g} \text { Carbon \#3 in } 75 \mathrm{~g} \\
\text { sand }\end{array}$ \\
\hline Packed Bed \#2 & $\begin{array}{c}0.25 \mathrm{~g} \text { Carbon \#6 in } 75 \mathrm{~g} \\
\text { sand }\end{array}$ & $3.75 \mathrm{~g} \mathrm{Pd} \mathrm{\# 1} \mathrm{in} 75 \mathrm{~g}$ sand & $1.5 \mathrm{~g} \mathrm{SBA} \# 5$ in $75 \mathrm{~g}$ sand \\
\hline
\end{tabular}

intermediate-length screening tests for carbon-based catalysts in April. However, the results in Figure 3-1 showed that two of the three tested would be expected to lose activity early in thelong-term test. Because it was desired to test two carbon-based catalysts, and because a single bed of Carbon \#3 had shown relatively high activity in the short-term tests, it was decided to include Carbon \#3 as the fourth catalyst and the second carbon catalyst for the long-term test.

Table 3-6 and Figure 3-2 show catalyst performance data over the long-term test period. The test equipment lost power prior to the final day of scheduled testing in November. Analyses of outlet elemental mercury concentrations had been completed for two of the five catalyst beds ( $\mathrm{Pd} \# 1$ and Carbon \#3) prior to the power outage. Due to the decrease in catalyst temperature and the 
Table 3-6

Catalyst Performance at the End of the Long-term Test at Site 2

\begin{tabular}{|c|c|c|c|c|c|c|}
\hline Catalyst & $\begin{array}{c}\text { Sample } \\
\text { Port }\end{array}$ & $\begin{array}{l}\text { Catalyst } \\
\text { Mass, mg }\end{array}$ & $\begin{array}{l}\text { Flue Ga } \\
\text { Hours }\end{array}$ & $\begin{array}{l}\text { Exposure } \\
\text { NL }\left(10^{3}\right)\end{array}$ & $\begin{array}{c}\text { Mercury } \\
\text { Adsorption } \\
\text { Breakthrough } \\
\text { (\% of Inlet } \mathrm{Hg})\end{array}$ & $\begin{array}{c}\text { Elemental } \\
\text { Mercury } \\
\text { Oxidation } \\
\text { (\% of Inlet } \mathrm{Hg})\end{array}$ \\
\hline Carbon \#6* & $1 a$ & 250 & 3192 & 478 & $76^{* *}$ & 40 \\
\hline Carbon \#6* & $1 b$ & 500 & 3192 & 478 & 54 & 78 \\
\hline $\mathrm{Pd} \# 1$ & $2 b$ & 3750 & 3864 & 583 & 75 & 96 \\
\hline Carbon \#3 & $3 a$ & 250 & 3864 & 635 & 100 & 0 \\
\hline SBA \#5* & $3 b$ & 1500 & 3192 & 515 & 66 & 87 \\
\hline
\end{tabular}

*October results are reported for these catalysts; November results are reported for the remaining catalysts.

**This value appears to be erroneously low, as the breakthrough measured in September and November was 100\%.

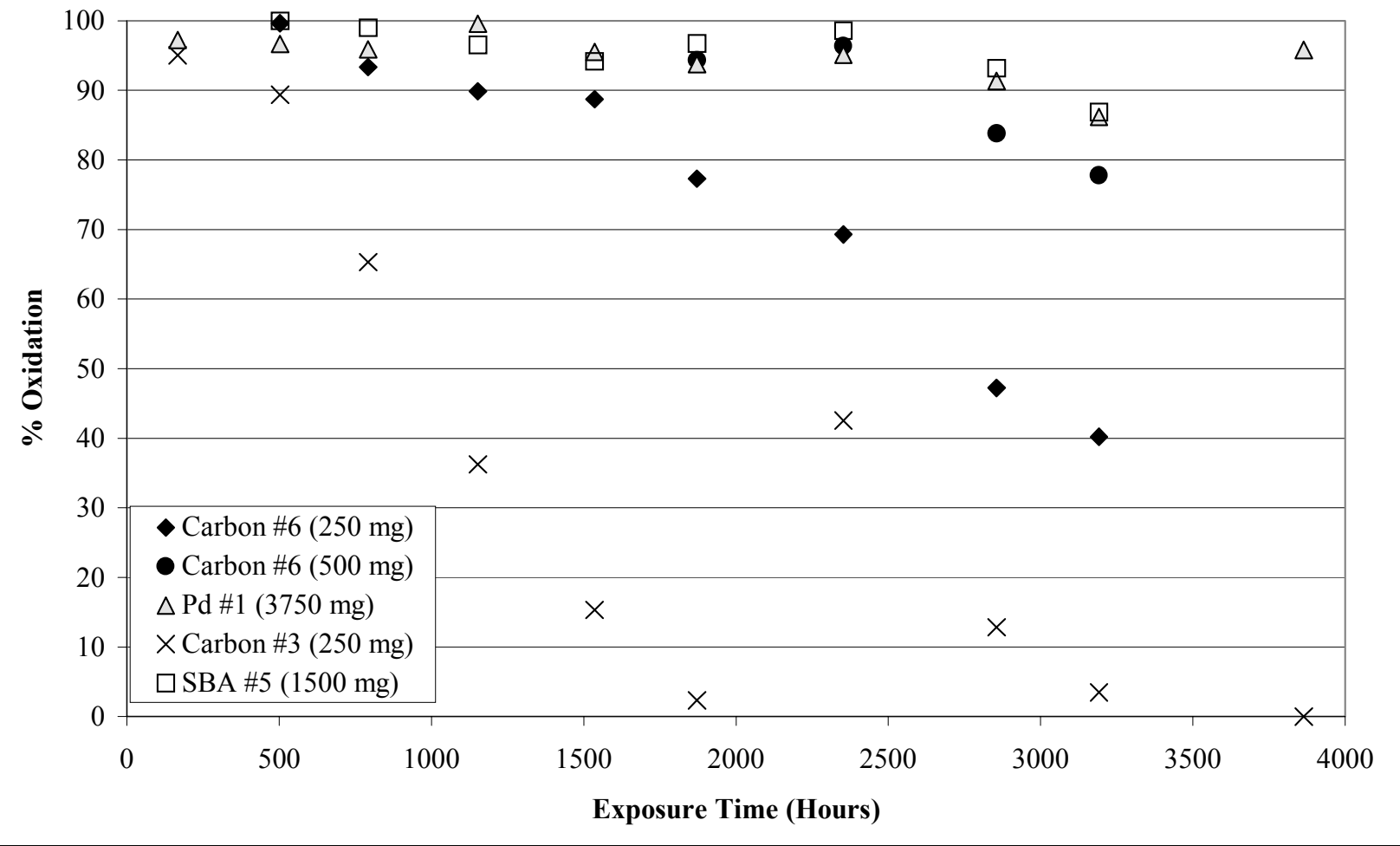

Figure 3-2

Effect of Flue Gas Exposure on Elemental Mercury Oxidation Activity at Site 2 
expected condensation of flue gas moisture and acid gas species on the catalyst beds during the power outage, the other three beds were not analyzed for performance after power was restored. Consequently, oxidation percentages at the end of the test are available for only two of the five catalysts. The adsorption capacities and oxidation results for each catalyst bed in Table 3-6 and Figure 3-2 correspond to the last time at which oxidation results were measured (i.e., November 1999 for Pd \#1 and Carbon \#3 and October 1999 for Carbon \#6 and SBA \#5).

November results ( $3864 \mathrm{hrs}$ ) indicated that the Pd \#1 showed no signs of significant deactivation, while the Carbon \#3 carbon appeared to be completely deactivated. After exposure to $583 \mathrm{Nm}^{3}$ $\left(583 \times 10^{3} \mathrm{NL}\right)$ of flue gas, Pd $\# 1$ oxidized $96 \%$ of the elemental mercury, while after exposure to $635 \mathrm{Nm}^{3}$, Carbon $\# 3$ oxidized none.

The remaining results presented in Table 3-6 and Figure 3-2 are from testing conducted in October, after $3192 \mathrm{hrs}$ of flue gas exposure. In October, the second bed of Carbon \#6 was achieving $78 \%$ oxidation of elemental mercury after having been exposed to $478 \mathrm{Nm}^{3}$ of flue gas. The upstream, 250-mg bed of Carbon \#6, which had begun to show measurable deactivation after about $1500 \mathrm{hrs}$ and exposure to $209 \mathrm{Nm}^{3}$ of flue gas, was oxidizing $40 \%$ of the elemental mercury. The second bed started showing signs of deactivation at about twice the exposure time and gas volume as the first bed, which suggests that deactivation occurred across the two beds in a linear relationship with the amount of flue gas treated.

The results in Figure 3-3 show that mercury oxidation by Carbon \#3 began to decrease steadily after about 500 hours and exposure to $74 \mathrm{Nm}^{3}$ of flue gas; Carbon $\# 3$ only showed $2 \%$ elemental mercury oxidation at the end of August. However, Carbon \#3 measured $43 \%$ oxidation in midSeptember. Results from late October showed only $3 \%$ mercury oxidation, suggesting that the September results reflect a measurement error. Measurements made in November confirmed that Carbon \#3 was completely deactivated. The ash-based SBA \#5 catalyst showed $87 \%$ oxidation in October, after $3192 \mathrm{hrs}$ and $515 \mathrm{Nm}^{3}$ of flue gas exposure.

In August, all of the catalysts appeared to be at adsorption equilibrium (corresponding to $100 \%$ mercury breakthrough in Table 3-6). The September results showed that the first bed of Carbon \#6 and Carbon \#3 were at equilibrium while the other samples showed low levels of adsorption occurring. This was evident by effluent "total" mercury levels being lower than the inlet levels. The October results indicated that only Carbon \#3 was at adsorption equilibrium. Adsorption results from November are shown for only two of the five beds in Table 3-6; October results are shown for the other three so as to be on the same basis as the oxidation results. However, the November results agreed with those obtained in September, showing that the first bed of Carbon $\# 6$ and the Carbon \#3 catalysts were at equilibrium while the other three showed low levels of adsorption occurring.

It is believed that the inconsistencies in the October adsorption results are due to analytical error. When the catalysts recovered from the field test unit were analyzed for adsorption capacities in the laboratory, all were at or near adsorption equilibrium. This indicates analytical error in the field. However, no flow problems, leaks, or residual mercury on the gold used in the analysis were identified in the field apparatus. At this time, it is uncertain as to the source of the error. 
It was an important finding that over the long-term test period, three of the five catalyst beds were able to achieve greater than $70 \%$ oxidation of the inlet elemental mercury. Of these, two (Carbon \#6 and SBA \#5) had begun showing signs of loss of activity. These two may not have been able to achieve the objective of this project of identifying catalysts that would achieve at least $70 \%$ oxidation for one year or greater. However, the Pd \#1 catalyst was still achieving 96\% oxidation after greater than five months in service, and showed no measurable trend for decreased activity with time.

\section{Commercial Catalyst Form Tests}

During the long-term testing of catalyst sand beds at Site 2, additional tests were conducted to evaluate the activity of catalysts in commercially viable configurations rather than as finely ground powders dispersed in sand, as are tested in the long-term test apparatus. Such configurations could include honeycomb supports (such as those used in SCR), pellets, and others. The objective of these tests was to evaluate promising catalysts identified in the longterm tests in commercially viable configurations and at area velocities consistent with reactor sizes used in the utility industry or smaller. SCR catalysts typically operate at area velocities ranging from 15 to 30 standard $\mathrm{ft} / \mathrm{hr}(4.3$ to $8.7 \mathrm{Nm} / \mathrm{hr})$. If mercury catalysts prove effective at similar or higher area velocities, it is likely that honeycomb support structures could be utilized in a reactor of a commercially viable size. Also, mercury oxidation catalysts operated downstream of the particulate control device (e.g., in clean gas) could employ a much tighter honeycomb pitch than in typical SCR applications. This would allow smaller reactor sizes at a given area velocity.

\section{Pellet Catalyst Form}

Over the last several months of the long-term test at Site 2, a number of tests were conducted to compare the performance of the Pd \#1 catalyst in pellet form to that in the sand bed reactor. Table 3-7 compares the area velocities, adsorption breakthrough and oxidation percentages associated with Pd \#1 in the sand bed reactor of the long-term test at Site 2 to those for the pellet reactors.

The first pellet reactor test was conducted with $40 \mathrm{~g}$ of pellets in the reactor and a flue gas flow rate of $27 \mathrm{NL} / \mathrm{min}$, and showed very high oxidation after two weeks of flue gas exposure. Subsequently another two-week test was conducted with a $20-\mathrm{g}$ bed of $\mathrm{Pd} \# 1$ pellets at a similar gas flow rate, resulting in twice the area velocity of the first test, at 210 standard $\mathrm{ft} / \mathrm{hr}(61$ $\mathrm{Nm} / \mathrm{hr}$ ). After two weeks, this second test showed that the catalyst had reached adsorption equilibrium and was oxidizing greater than $97 \%$ of the elemental mercury. A set with $5 \mathrm{~g}$ of pellets was subsequently exposed to flue gas at a similar rate for a similar time period, resulting in an area velocity of $860 \mathrm{standard} \mathrm{ft} / \mathrm{hr}(250 \mathrm{Nm} / \mathrm{hr})$. At this high area velocity mercury oxidation dropped to about $67 \%$. To pinpoint the maximum area velocity at which high oxidation efficiency could be achieved, a test of a 10-g sample was conducted. Results from that test showed $77 \%$ oxidation of the elemental mercury in the treated gas. Mercury adsorption could not be measured due to analytical problems. 
Table 3-7

Area Velocities Tested for Pd \#1

\begin{tabular}{|c|c|c|c|c|c|}
\hline Catalyst Form & $\begin{array}{c}\text { Catalyst } \\
\text { Mass } \\
\mathbf{( g )}\end{array}$ & $\begin{array}{c}\text { Area Velocity } \\
\text { (std. ft/hr) }^{*}\end{array}$ & $\begin{array}{c}\text { Flue Gas } \\
\text { Exposure } \\
\left.\text { (Nm }^{3}\right)\end{array}$ & $\begin{array}{c}\text { \% } \\
\text { Breakthrough } \\
\text { of Total } \mathbf{~ H g}\end{array}$ & $\begin{array}{c}\text { \% Oxidation } \\
\text { of Elemental } \\
\text { Hg }\end{array}$ \\
\hline Sand Bed & 3.75 & $165^{\star *}$ & 583 & 75 & 96 \\
\hline Pellet & 40 & 110 & 370 & 77 & 95 \\
\hline Pellet & 20 & 210 & 402 & 100 & 97 \\
\hline Pellet & 5 & 860 & 323 & 86.3 & 67 \\
\hline Pellet & 10 & 430 & 175 & - & 77 \\
\hline
\end{tabular}

* One std. ft/hr $=0.29 \mathrm{Nm} / \mathrm{hr}$.

** Area velocity estimated based on amount of palladium present in the sample. This assumes that the palladium is present at the surface of the ground Pd \#1 beads at a percentage of the total particle surface area that is equivalent to the mass fraction on the original pellets.

Greater than $70 \%$ mercury oxidation was achieved at an area velocity over an order of magnitude greater than that typical of SCR catalysts, and nearly $100 \%$ oxidation was achieved at an area velocity about seven times greater. These results suggested that high mercury oxidation efficiencies could be achieved with a reactor much smaller than is typically required for SCR applications.

\section{Monolith (Honeycomb) Catalyst Structure}

To evaluate the effect of catalyst structure on performance, we obtained the Pd \#1 catalyst on a honeycomb structure. The honeycomb, coated with the same palladium material as the Pd \#1 pellet catalyst, has dimensions based on those used in "clean side" SCR applications: a cell density of $64 \mathrm{cpsi}$, a 3.2-mm pitch, and a geometric surface area of about $340 \mathrm{ft}^{2} / \mathrm{ft}^{3}(1100$ $\left.\mathrm{m}^{2} / \mathrm{m}^{3}\right)$.

In early October, tests were begun at Site 2 with four 2-inch-long (5-cm-long) honeycomb structures. The structures were arranged in sets of two in series and exposed to flue gas at area velocities ranging from 74 to 260 standard ft/ $/ \mathrm{hr}$ ( 21 to $75 \mathrm{Nm} / \mathrm{hr}$ ). The superficial velocities ranged from 2.3 to 4.5 standard ft/sec $(0.66$ to $1.3 \mathrm{Nm} / \mathrm{s})$. Testing of Pd \#1 on a honeycomb substrate continued into November.

Upon returning to the site in November, it was discovered that flow through honeycomb catalyst set \#1 had ceased due to a failure of the flue gas pump. A similar pump failure was experienced earlier in October. Since another pump was not available and the prior loss of flow had already resulted in uncertain flue gas exposure, it was decided to conduct no further testing on set \#1. Thus, the only results presented for honeycomb catalyst set \#1 are from October. 
The loss of flow through honeycomb catalyst set \#1 resulted in greater flow through set \#2. The flow rate increase correspondingly increased the area velocity from 136 to 194 standard ft/hr (39 to $56 \mathrm{Nm} / \mathrm{hr}$ ) through catalyst $2 \mathrm{a}$ and from 74 to 105 standard $\mathrm{ft} / \mathrm{hr}$ ( 21 to $30 \mathrm{Nm} / \mathrm{hr}$ ) through catalyst 2 b. Results from these tests are summarized in Table 3-8. At the high area velocities tested in November, catalyst $2 \mathrm{a}$ oxidized $51 \%$ and catalyst $2 \mathrm{~b}$ oxidized $56 \%$ of the elemental mercury present in the treated gas.

Table 3-8

Performance of Pd \#1 on a Honeycomb Structure at Site 2

\begin{tabular}{|c|c|c|c|c|c|c|}
\hline \multirow[b]{2}{*}{ Port } & \multirow{2}{*}{$\begin{array}{l}\text { Area Velocity* } \\
\text { (std. ft/hr) }\end{array}$} & \multirow{2}{*}{$\begin{array}{l}\text { Superficial Velocity** } \\
\text { (std. ft/sec) }\end{array}$} & \multicolumn{2}{|c|}{ Flue Gas Exposure } & \multirow{2}{*}{$\begin{array}{c}\% \\
\text { Breakthrough }\end{array}$} & \multirow{2}{*}{$\begin{array}{c}\% \\
\text { Oxidation }\end{array}$} \\
\hline & & & Hours & $\mathrm{Nm}^{3}$ & & \\
\hline $1 \mathrm{a}$ & 242 & 3.7 & 479 & 936 & - & 46 \\
\hline $1 b$ & 116 & 3.7 & 480 & 936 & - & 42 \\
\hline $2 \mathrm{a}$ & 194 & 3.3 & 961 & 908 & 73 & 51 \\
\hline $2 b$ & 105 & 3.3 & 962 & 909 & 69 & 56 \\
\hline
\end{tabular}

$* 1$ std. $\mathrm{ft} / \mathrm{hr}=0.29 \mathrm{Nm} / \mathrm{hr}$.

$* * 1 \mathrm{std} . \mathrm{ft} / \mathrm{sec}=0.29 \mathrm{Nm} / \mathrm{s}$.

Total mercury measurements showed that catalysts $2 \mathrm{a}$ and $2 \mathrm{~b}$ were achieving $73 \%$ and $69 \%$ total mercury breakthrough, respectively.

Because of the malfunctioning pump, the actual amount of flue gas exposure for each set of catalysts is uncertain. The times of the pump failures were estimated as halfway between times when flow was verified. Based on this assumption, honeycomb catalyst set \#1 oxidized 42 to $46 \%$ of the elemental mercury in the flue gas after having been exposed to $936 \mathrm{Nm}^{3}$ of flue gas, and honeycomb set $\# 2$ achieved 51 to $56 \%$ oxidation after exposure to $909 \mathrm{Nm}^{3}$ of flue gas.

The validity of the October oxidation results is uncertain. As seen in Table 3-8, the measurement made at the " $1 \mathrm{~b}$ " port, located downstream of the two honeycomb catalysts in series, shows a lower oxidation percentage than that at the "1a" port, located downstream of the first honeycomb. Due to the greater catalyst surface area, the " $1 \mathrm{~b}$ " measurement corresponds to a lower area velocity than the "1a" measurement and should, therefore, show equal or better oxidation.

Possible reasons for inaccurate analyses include $\mathrm{SnCl}_{2}$ contamination within the test unit or problems associated with elemental mercury not completely desorbing from the gold amalgam in the analytical unit during each test run. The November results do not have the same inconsistencies as the October results. Measurements made downstream of the second catalyst bed reveal greater oxidation and greater adsorption of mercury, as would be expected.

The oxidation by the honeycomb catalysts did not compare well with the oxidation by the Pd \#1 pellets at similar area velocities. Whereas at 194 standard $\mathrm{ft} / \mathrm{hr}(56 \mathrm{Nm} / \mathrm{hr})$ the honeycomb 
oxidized $51 \%$ of the elemental mercury, at a slightly higher area velocity of 210 standard $\mathrm{ft} / \mathrm{hr}$ $(61 \mathrm{Nm} / \mathrm{hr}$ ) the Pd \#1 pellets showed $97 \%$ oxidation. The negligible deactivation of the $\mathrm{Pd} \# 1$ in the long-term sand bed test suggests that loss of activity due to flue gas exposure would not be the cause of the lower oxidation. The lower oxidation by the honeycomb could instead be a result of insufficient catalyst loading on the honeycomb surface (e.g., insufficient grams of Pd per $\mathrm{ft}^{2}$ of honeycomb to ensure very high surface reaction rates) or due to inadequate flue gas contact with the catalyst surface. The latter could be a result of diffusion of elemental mercury from the bulk flue gas to the honeycomb surface controlling the overall reaction rate.

To determine what factor had a detrimental effect on oxidation, honeycomb samples with greater catalyst loadings were ordered and have been received. Laboratory tests will be conducted with these honeycombs to determine if increased oxidation results at higher palladium loading.

In parallel, mass transfer calculations are being conducted to model elemental mercury conversion in the honeycomb reactor versus the pellet reactor. For these calculations, the reaction rate is assumed to be instantaneous at the catalyst surface (i.e., reaction kinetics are assumed not to control the overall reaction rate). These calculations are intended to indicate the extent to which mercury diffusion from the flue gas to the honeycomb surface controls the overall conversion, relative to that for the pellet reactor.

The results of these calculations show that both mercury diffusion rates and palladium loading may impact the performance of the honeycomb catalyst relative to the pellet catalyst beds. They show that at similar area velocity values, the predicted mercury oxidation is higher for the pellet bed than for the honeycomb, with the honeycomb performance being limited by the rate of mercury diffusion to the honeycomb surface. The calculation results also show that the measured performance of the honeycomb catalyst falls well short of the predicted mercury oxidation based on "instantaneous" oxidation at the surface, while the measured pellet catalyst results nearly equal the predicted results for that configuration. This may indicate that the palladium loading on the honeycomb surface was not sufficient to provide nearly instantaneous reaction rates, but the higher effective loading per surface area on the pellets was adequate. Future laboratory testing should be able to determine if this is the case. 


\section{LABORATORY TEST RESULTS}

Laboratory testing has been conducted throughout Phase II to support the field tests. For Site 2, laboratory tests have been conducted to screen catalysts for effectiveness at simulated Site 2 flue gas conditions and some alternate flue gas conditions, to determine the effectiveness of the laboratory unit for screening catalyst life, and to attempt regeneration of catalysts recovered from tests at Site 2. Each of these laboratory test efforts is discussed below.

\section{Catalyst Screening Tests}

Prior to field testing, bench-scale tests are conducted to screen catalyst materials at flue gas conditions similar to each test site. This allows the field effort to focus on only the more active catalysts for a particular flue gas composition. Table 4-1 lists the gas compositions for the Site 2 simulation tests. Actual gas compositions that were subsequently measured at Site 2 are also shown in the table. In most instances the assumed values used for the simulation gas were very close to the values that were later measured for the actual flue gas.

Table 4-1

Simulated Flue Gas Compositions for Bench-Scale Tests

\begin{tabular}{|c|c|c|}
\hline Flue Gas Parameter & Site \#2 Simulation Gas & Measured Site \#2 Gas Conditions \\
\hline $\mathrm{O}_{2}(\%)$ & 7 & $6-14$ \\
\hline $\mathrm{SO}_{2}(\mathrm{ppm})$ & 200 & $250-350$ \\
\hline $\mathrm{SO}_{3}(\mathrm{ppm})$ & 0 & $<0.2$ \\
\hline $\mathrm{CO}_{2}(\%)$ & 13 & $11-13$ \\
\hline $\mathrm{HCl}(\mathrm{ppm})$ & $1^{*}$ & $130-200$ \\
\hline $\mathrm{NO}_{x}(\mathrm{ppm})$ & 200 & 12 \\
\hline $\mathrm{H}_{2} \mathrm{O}(\%)$ & 10 & $9-25$ \\
\hline $\mathrm{Hg}^{0}\left(\mu \mathrm{g} / \mathrm{Nm}^{3}\right)$ & $20-40$ & $300(149)$ \\
\hline Temperature $\left[{ }^{\circ} \mathrm{F}\left({ }^{\circ} \mathrm{C}\right)\right]$ & $300(149)$ & 130 \\
\hline
\end{tabular}

*Some early tests were conducted with no $\mathrm{HCl}$ in the simulation gas 
Table 4-2 compares laboratory results to catalyst screening test results performed with the actual flue gas at Site 2. Oxidation measurements were made after the catalysts stopped adsorbing mercury. For most catalysts, the laboratory and field results were in close agreement. However, several catalysts performed better and some worse in actual flue gas than in lab tests. This suggests that trace flue gas components not added to the simulation gas may affect the performance of some catalysts.

Table 4-2

Comparison of Lab and Field Catalyst Screening Test Results for Site 2

\begin{tabular}{|c|c|c|}
\hline \multirow{2}{*}{ Catalyst Type } & \multicolumn{2}{|c|}{ Elemental Mercury Oxidation Across Catalyst Bed, \% } \\
\cline { 2 - 3 } & Field & 0 \\
\hline Sand & 2 & 77 \\
\hline Carbon \#1 & 78 & 80 \\
\hline Carbon \#2 & $61^{*}$ & 63 \\
\hline Carbon \#3 & 77 & 11 \\
\hline Carbon \#4 & $89^{*}$ & 0 \\
\hline Carbon \#5 & $50^{*}$ & 100 \\
\hline Carbon \#6 & 82 & 70 \\
\hline SBA \#5 & 80 & 8 \\
\hline Fe \#1 & 29 & 90 \\
\hline Pd \#1 & 90 & 95 \\
\hline Pd \#3 & 92 & 20 (2) \\
\hline
\end{tabular}

*First fixed bed showed lower oxidation than the second (listed) indicating some deactivation.

The laboratory results in Table 4-2 all were generated using a simulation gas with $1 \mathrm{ppm}$ of $\mathrm{HCl}$. Earlier bench-scale tests performed in the absence of $\mathrm{HCl}$ generally showed poor catalyst performance, suggesting the participation of $\mathrm{HCl}$ in the mercury adsorption and oxidation mechanisms. A comparison of lab results with and without $\mathrm{HCl}$ in the simulation gas is shown in Table 4-3. While the performance of most catalyst materials improved when $1 \mathrm{ppm}$ of $\mathrm{HCl}$ was added to the simulation gas, the performance of some degraded. One of the iron-based catalysts, $\mathrm{Fe} \# 1$, showed the greatest loss of activity, suggesting that $\mathrm{HCl}$ is a poison for that particular catalyst.

Laboratory experiments were also conducted to examine the effect of $\mathrm{NO}_{\mathrm{X}}$ concentration (primarily NO) on the mercury adsorption and oxidation performance of three catalyst materials. Phase I results showed that it was important that $\mathrm{NO}_{\mathrm{X}}$ be present in the laboratory simulation gas. Since the range of $\mathrm{NO}_{\mathrm{x}}$ concentrations encountered at coal-fired units could range from very 
Table 4-3

Equilibrium Adsorption Capacity and Mercury Oxidation for Catalysts in Site 2 Simulation Gas with and without 1 ppm $\mathrm{HCl}$

\begin{tabular}{|c|c|c|c|c|c|c|}
\hline \multirow[b]{2}{*}{ Sample Type } & \multirow[b]{2}{*}{ Sample } & \multirow{2}{*}{$\begin{array}{c}\text { Sample } \\
\text { Loading } \\
\text { (mg Sample } \\
\text { /g Sand }\end{array}$} & \multicolumn{2}{|c|}{$\begin{array}{l}\text { Adsorption Capacity } \\
\text { ( } \mu \mathrm{g} \mathrm{Hg}^{0} / \mathrm{g} \text { Sample) }\end{array}$} & \multicolumn{2}{|c|}{$\begin{array}{c}\text { Mercury Oxidation } \\
\text { (\% Inlet })\end{array}$} \\
\hline & & & No $\mathrm{HCl}$ & $\begin{array}{c}1 \mathrm{ppm} \\
\mathrm{HCl}\end{array}$ & $\mathrm{No} \mathrm{HCl}$ & $\begin{array}{c}1 \mathrm{ppm} \\
\mathrm{HCl}\end{array}$ \\
\hline \multirow[t]{8}{*}{ Carbon } & Carbon \#1 & 2 & 28 & 624 & 1 & 77 \\
\hline & Carbon \#2 & 2 & 1549 & 1308 & 89 & 80 \\
\hline & Carbon \#3 & 2 & 157 & 266 & 49 & 63 \\
\hline & Carbon \#4 & 2 & 58 & 29 & 0 & 11 \\
\hline & Carbon \#5 & 2 & 5741 & 5911 & 32 & 0 \\
\hline & Carbon \#5a & 2 & 86 & 80 & 2 & 79 \\
\hline & Carbon \#6 & 2 & 258 & 401 & 55 & 100 \\
\hline & Carbon \#6a & 2.2 & 97 & 614 & 0 & 100 \\
\hline \multirow[t]{3}{*}{ Fly Ash (Bituminous) } & BA \#2a & 20 & 0 & 2 & 0 & 34 \\
\hline & BA \#3 & 20 & 3 & 0 & 0 & 88 \\
\hline & BA \#16 & 20 & 1 & 0 & 11 & 0 \\
\hline \multirow{5}{*}{$\begin{array}{c}\text { Fly Ash } \\
\text { (Subbituminous) }\end{array}$} & SBA \#1 & 20 & 0 & 0 & 1 & 0 \\
\hline & SBA \#2 & 20 & 0 & 0 & 0 & 0 \\
\hline & SBA \#3 & 20 & 1 & 3 & 0 & 28 \\
\hline & SBA \#4 & 20 & 2 & 11 & 17 & 96 \\
\hline & SBA \#5 & 2,20 & 56 & 150 & 2 & 70 \\
\hline \multirow[t]{2}{*}{ Fly Ash (Lignite) } & LA \#1 & 20 & 1 & 0 & 6 & 0 \\
\hline & LA \#3 & 20 & 11 & 0 & 6 & 0 \\
\hline \multirow[t]{2}{*}{ Fly Ash (Oil) } & OFA & 20 & 0 & 0 & 18 & 0 \\
\hline & OFA \#2 & 20 & 0 & 0 & 0 & 81 \\
\hline Metal/Catalyst & $\mathrm{Fe} \# 1$ & 20 & 8 & 7 & 57 & 8 \\
\hline
\end{tabular}


Table 4-3

Equilibrium Adsorption Capacity and Mercury Oxidation for Catalysts in Site 2 Simulation Gas with and without $1 \mathrm{ppm} \mathrm{HCl}$ (continued)

\begin{tabular}{|c|c|c|c|c|c|c|}
\hline \multirow[b]{2}{*}{ Sample Type } & \multirow[b]{2}{*}{ Sample } & \multirow{2}{*}{$\begin{array}{c}\text { Sample } \\
\text { Loading } \\
\text { (mg Sample } \\
\text { /g Sand }\end{array}$} & \multicolumn{2}{|c|}{$\begin{array}{c}\text { Adsorption Capacity } \\
\text { ( } \mu \mathrm{g} \mathrm{Hg} / \mathrm{g} \text { Sample) }\end{array}$} & \multicolumn{2}{|c|}{$\begin{array}{c}\text { Mercury Oxidation } \\
\text { (\% Inlet })\end{array}$} \\
\hline & & & $\mathrm{No} \mathrm{HCl}$ & $\begin{array}{c}1 \mathrm{ppm} \\
\mathrm{HCl}\end{array}$ & $\mathrm{No} \mathrm{HCl}$ & $\begin{array}{c}1 \mathrm{ppm} \\
\mathrm{HCl}\end{array}$ \\
\hline & $\mathrm{Fe} \# 2$ & 20 & 1 & 0 & 0 & 0 \\
\hline & $\mathrm{Fe} \# 5$ & 20 & 0 & 0 & 16 & 0 \\
\hline & $\mathrm{Ni} \# 1$ & 2,20 & 7 & 0 & 4 & 0 \\
\hline & $P d \# 1$ & 20 & 26 & 30 & 77 & 90 \\
\hline & $\mathrm{Pd} \# 3$ & 20 & 7 & 4 & 96 & 95 \\
\hline & SCR & 20 & 3 & 3 & 10 & 0 \\
\hline & Zn \#1 & 20 & 0 & 0 & 0 & 0 \\
\hline
\end{tabular}

low concentrations for units with selective catalytic reduction to very high for cyclone-fired units, these tests were conducted to determine how variations in flue gas $\mathrm{NO}_{\mathrm{X}}$ concentration affected catalyst performance.

The baseline gas for these tests was simulated Site 2 gas containing $1 \mathrm{ppm}$ of $\mathrm{HCl}$. The results in Table 4-4 show that increasing the $\mathrm{NO}_{\mathrm{X}}$ concentration to as high as $800 \mathrm{ppm}$ decreased Carbon \#1 catalyst oxidation performance slightly and greatly reduced its adsorption capacity. However, when no $\mathrm{NO}_{\mathrm{X}}$ was present, the oxidation performance of Carbon \#1 was worse than even at the high $\mathrm{NO}_{\mathrm{X}}$ concentration. These results suggest that, like $\mathrm{HCl}, \mathrm{NO}_{\mathrm{X}}$ plays a role in the catalytic oxidation of mercury.

For SBA \#5 and $\mathrm{Pd} \# 1$ the role of $\mathrm{NO}_{\mathrm{X}}$ was less dramatic. For SBA \#5 the adsorption capacity appeared to generally increase with $\mathrm{NO}_{\mathrm{X}}$ concentration. As for Carbon \#1, the oxidation percentage appeared to decrease at the highest $\mathrm{NO}_{\mathrm{X}}$ concentration and even more so with no $\mathrm{NO}_{\mathrm{X}}$ present. However, the effect was less pronounced than for Carbon \#1. For Pd \#1, the adsorption capacity appeared to decrease with increasing $\mathrm{NO}_{\mathrm{X}}$ concentration. As with the other catalysts tested, the oxidation performance measured was lowest with no $\mathrm{NO}_{\mathrm{X}}$ in the simulation gas, and there was a slight reduction in performance at the highest $\mathrm{NO}_{\mathrm{X}}$ concentration.

These results support the Phase I finding that the laboratory simulation gas must contain $\mathrm{NO}_{\mathrm{X}}$ to adequately simulate field performance. They also suggest that, while $\mathrm{NO}_{\mathrm{X}}$ appears to play a role in mercury oxidation, over the range of $\mathrm{NO}_{\mathrm{X}}$ concentrations encountered in most pulverized coal boilers, the actual $\mathrm{NO}_{\mathrm{X}}$ concentration in the flue gas will not greatly impact mercury catalyst performance. 
Table 4-4

Effect of $\mathrm{NO}_{x}$ Concentration on the Performance of Carbon \# 1 at $300^{\circ} \mathrm{F}\left(149^{\circ} \mathrm{C}\right)$, Site 2 Simulated Conditions (with $\mathrm{HCl}$ )

\begin{tabular}{|c|c|c|c|c|c|c|}
\hline \multirow[b]{2}{*}{$\begin{array}{c}\mathrm{NO}_{\mathrm{x}} \\
\text { Concentration } \\
\text { (ppm) }\end{array}$} & \multicolumn{2}{|c|}{ Carbon \#1 } & \multicolumn{2}{|c|}{ SBA \#5 } & \multicolumn{2}{|c|}{$P d \# 1$} \\
\hline & $\begin{array}{c}\text { Adsorption } \\
\text { Capacity } \\
\left(\mu \mathrm{Hg}^{0} / \mathrm{g}\right. \\
\text { Sample) }\end{array}$ & $\begin{array}{c}\text { Elemental } \\
\text { Hg } \\
\text { Oxidation } \\
\text { (\% Inlet) }\end{array}$ & $\begin{array}{c}\text { Adsorption } \\
\text { Capacity } \\
\left(\mu \mathrm{Hg}^{0} / \mathrm{g}\right. \\
\text { Sample) }\end{array}$ & $\begin{array}{c}\text { Elemental } \\
\text { Hg } \\
\text { Oxidation } \\
\text { (\% Inlet) }\end{array}$ & $\begin{array}{c}\text { Adsorption } \\
\text { Capacity } \\
\left(\mu \mathrm{Hg}^{0} / \mathrm{g}\right. \\
\text { Sample) }\end{array}$ & $\begin{array}{c}\text { Elemental } \\
\text { Hg } \\
\text { Oxidation } \\
\text { (\% Inlet) }\end{array}$ \\
\hline 0 & 1230 & 58 & 287 & 81 & 41 & 72 \\
\hline 10 & - & - & - & - & 29 & 91 \\
\hline 25 & 1192 & 98 & - & - & 21 & 96 \\
\hline 50 & - & - & 309 & 100 & - & - \\
\hline 100 & 1979 & 88 & 323 & 94 & 10 & 91 \\
\hline 200 & 624 & 88 & 145 & 100 & 30 & 89 \\
\hline 400 & 776 & 88 & 325 & 96 & - & - \\
\hline 600 & 587 & 69 & 322 & 96 & 8 & 89 \\
\hline 800 & 284 & 77 & 433 & 83 & 5 & 86 \\
\hline
\end{tabular}

A number of tests were conducted with Carbon \#1 to determine the effects of the form of the $\mathrm{NO}_{\mathrm{X}}$ present (NO for the "NO " tests vs. $\mathrm{NO}_{2}$ ). The results of these tests are summarized in Table 4-5. Table 4-5 also includes the results from Table 4-4 on the effects of $\mathrm{NO}_{\mathrm{X}}$ (predominantly NO) on the performance of Carbon \#1. The results show that $\mathrm{NO}_{2}$ significantly lowers catalyst adsorption capacity relative to that with $\mathrm{NO}$, but its effects on mercury oxidation are almost identical to those of $\mathrm{NO}$. This suggests that the $\mathrm{NO}$-to- $\mathrm{NO}_{2}$ ratio in the laboratory simulation gas or in actual flue gases encountered in the field will not greatly impact catalyst oxidation results.

Finally, some laboratory tests were conducted at a simulated flue gas temperature of $700^{\circ} \mathrm{F}$ $\left(371^{\circ} \mathrm{C}\right)$. Over the next several years, a number of utilities will likely have to retrofit SCR units for control of $\mathrm{NO}_{\mathrm{X}}$ emissions from their coal-fired boilers. It is possible that SCR catalysts would also catalyze the oxidation of elemental mercury or that mercury catalyst materials could be added to the SCR reactors. All of the catalyst testing to date in Phase II has been conducted at gas temperatures of about $300^{\circ} \mathrm{F}\left(149^{\circ} \mathrm{C}\right)$. However, the temperatures in SCR reactors are substantially higher $\left[\sim 700^{\circ} \mathrm{F}\left(371^{\circ} \mathrm{C}\right)\right]$. Therefore, mercury adsorption and oxidation by a sample of an SCR catalyst and by several known mercury oxidation catalyst materials were tested at $700^{\circ} \mathrm{F}\left(371^{\circ} \mathrm{C}\right)$.

From the results summarized in Table 4-6, the potential of this approach does not look promising. None of the catalyst materials tested showed substantial mercury oxidation activity; 
Table 4-5

Effect of $\mathrm{NO}_{2}$ Concentration on the Performance of Carbon \# 1 at $300^{\circ} \mathrm{F}\left(149^{\circ} \mathrm{C}\right)$, Site 2 Simulated Conditions (with $\mathrm{HCl}$ )

\begin{tabular}{|c|c|c|c|c|}
\hline \multirow[b]{2}{*}{$\begin{array}{c}\mathrm{NO}_{\mathbf{x}} / \mathrm{NO}_{2} \\
\text { Concentration } \\
(\mathrm{ppm})\end{array}$} & \multicolumn{2}{|c|}{$\mathrm{NO}_{\mathrm{x}}$ Predominantly as NO } & \multicolumn{2}{|c|}{$\mathrm{NO}_{\mathrm{X}}$ Present as $\mathrm{NO}_{2}$} \\
\hline & $\begin{array}{c}\text { Adsorption } \\
\text { Capacity } \\
\text { ( } \mu \mathrm{g} \mathrm{Hg} / \mathrm{g} \text { Sample) }\end{array}$ & $\begin{array}{c}\text { Elemental Hg } \\
\text { Oxidation } \\
\text { (\% Inlet) }\end{array}$ & $\begin{array}{c}\text { Adsorption } \\
\text { Capacity } \\
(\mu \mathrm{g} \mathrm{Hg} / \mathrm{g} \\
\text { Sample) }\end{array}$ & $\begin{array}{c}\text { Elemental Hg } \\
\text { Oxidation } \\
\text { (\% Inlet) }\end{array}$ \\
\hline 0 & 1230 & 58 & 1072 & 47 \\
\hline 5 & - & - & 1275 & 100 \\
\hline 10 & - & - & 894 & 98 \\
\hline 20 & - & - & 299 & 97 \\
\hline 25 & 1192 & 98 & - & - \\
\hline 30 & - & - & 339 & 100 \\
\hline 40 & - & - & 213 & 95 \\
\hline 50 & - & - & 337 & 90 \\
\hline 100 & 1979 & 88 & 99 & 87 \\
\hline
\end{tabular}

the highest mercury oxidation percentage was less than $10 \%$. However, these tests were conducted early on in the Site 2 investigations and, therefore, without $\mathrm{HCl}$ in the simulation gas. Some of the materials tested at $700^{\circ} \mathrm{F}\left(371^{\circ} \mathrm{C}\right)$ without $\mathrm{HCl}$ in the gas improved in oxidation performance at $300^{\circ} \mathrm{F}\left(149^{\circ} \mathrm{C}\right)$ when $\mathrm{HCl}$ was added to the simulation gas (Carbon \#1, SBA \#5,

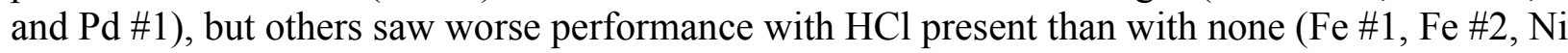
$\# 1$, and SCR catalyst). It remains a question whether any of these catalysts would have proven substantially more active at $700^{\circ} \mathrm{F}\left(371^{\circ} \mathrm{C}\right)$ with $\mathrm{HCl}$ in the flue gas. Future testing will be conducted with several catalyst materials at $700^{\circ} \mathrm{F}\left(371^{\circ} \mathrm{C}\right)$ with a more complete simulated flue gas matrix. However, since most near-term SCR retrofits will be on plants that fire bituminous coal, these laboratory simulations will be done with a simulated bituminous coal flue gas rather than at Site 2 simulation conditions.

\section{Laboratory Catalyst Deactivation Testing}

Some laboratory testing has been conducted to measure catalyst deactivation rates under simulated flue gas conditions. In these tests, the catalyst loading in the laboratory sand bed is reduced to the point where the initial elemental mercury oxidation is only 80 to $90 \%$. If the quantity were sufficient to achieve $100 \%$ oxidation, there could be a substantial excess of catalyst present, which could require long run times before measurable activity loss was observed. 
Table 4-6

Effect of Temperature on Adsorption and Oxidation Performance at Simulated Site 2 Conditions (No $\mathrm{HCl}$ )

\begin{tabular}{|c|c|c|c|c|c|c|}
\hline \multirow[b]{2}{*}{ Sample Type } & \multirow[b]{2}{*}{ Sample } & \multirow[b]{2}{*}{$\begin{array}{l}\text { Sample Loading } \\
\text { (mg sample/g sand) }\end{array}$} & \multicolumn{2}{|c|}{$\begin{array}{c}\text { Adsorption Capacity } \\
\text { (mg Hg } / \mathrm{g} \text { sample) }\end{array}$} & \multicolumn{2}{|c|}{$\begin{array}{l}\text { Elemental Mercury } \\
\text { Oxidation } \\
(\%)\end{array}$} \\
\hline & & & $\begin{array}{l}300^{\circ} \mathrm{F} \\
\left(149^{\circ} \mathrm{C}\right)\end{array}$ & $\begin{array}{l}700^{\circ} \mathrm{F} \\
\left(371^{\circ} \mathrm{C}\right)\end{array}$ & $\begin{array}{l}300^{\circ} \mathrm{F} \\
\left(149^{\circ} \mathrm{C}\right)\end{array}$ & $\begin{array}{l}700^{\circ} \mathrm{F} \\
\left(371^{\circ} \mathrm{C}\right)\end{array}$ \\
\hline Carbon & Carbon \#1 & 2 & 28 & 0 & 1 & 0 \\
\hline Fly Ash & SBA \#5 & 20 & 56 & 0 & 2 & 8 \\
\hline \multirow[t]{5}{*}{ Metal/Catalyst } & Fe \#1 & 20 & 8 & 0 & 57 & 0 \\
\hline & $\mathrm{Fe} \# 2$ & 20 & 1 & 0 & 0 & 0 \\
\hline & $\mathrm{Ni} \# 1$ & 20 & 7 & 0 & 4 & 0 \\
\hline & $\mathrm{Pd} \# 1$ & 20 & 26 & 2 & 77 & 2 \\
\hline & SCR catalyst & 20 & 3 & 0 & 10 & 0 \\
\hline
\end{tabular}

The objective of these tests is to try to elucidate mechanisms for loss of activity. Since the laboratory simulated flue gas composition is controlled, and does not contain trace species, it would be possible to vary flue gas compositions to determine the effects of individual gas species on loss of activity. Such information may allow mechanisms for loss of activity to be inferred.

Table 4-7 contains a summary of deactivation tests for lab and field (Site 2) sand beds. Deactivation rates in the table should be interpreted as order-of-magnitude estimates. The deactivation rates in the table have been normalized for sorbent mass and total flue gas exposure. A lower deactivation rate signifies a catalyst that remains active for a longer time.

The normalized laboratory results show some agreement with the field observations, in that Carbon \#3 deactivated more rapidly than Carbon \#6. However, the field samples tended to deactivate at a much lower normalized rate than the lab samples. Also, the deactivation rate for $\mathrm{Pd} \# 1$ in the laboratory was similar to that of Carbon \#6, while in the field the Pd \#1 deactivation rate was much lower than for either of the carbon-based catalysts.

The field samples were exposed to flue gas at a much lower area velocity than were the laboratory beds. This result could indicate that the flue gas rate, not just the overall exposure per mass of catalyst, is important to catalyst life. If this proves to be the case, the benefits from operating at a lower area velocity (i.e., using more catalyst) would have to be balanced against catalyst cost constraints. However, it could also be differences in the field versus laboratory gas compositions (e.g., trace species) that account for the differences between the lab and field deactivation rate results. The effectiveness of laboratory tests as a screening tool for evaluating 
Table 4-7

Observed Deactivation Rates for Sand-bed Catalysts in the Laboratory and Field

\begin{tabular}{|c|c|c|c|c|}
\hline $\begin{array}{c}\text { Catalyst/ Test } \\
\text { Type }\end{array}$ & $\begin{array}{l}\text { Catalyst Loading, } \\
\mathrm{mg} /(\mathrm{L} / \mathrm{min})\end{array}$ & $\begin{array}{l}\text { Area Velocity, } \\
\text { std. ft/hr* }\end{array}$ & $\begin{array}{c}\text { Flue Gas } \\
\text { Exposure, } \mathrm{NL}^{* *}\end{array}$ & $\begin{array}{c}\text { Deactivation Rate,\% } \\
\text { Oxidation/(mg-NL) }\end{array}$ \\
\hline \multicolumn{5}{|c|}{ Carbon \#3: } \\
\hline Laboratory & 2.5 & 80 & 1946 & $8 \times 10^{-3}$ \\
\hline Laboratory & 10 & 20 & 9141 & $9 \times 10^{-4}$ \\
\hline Field Bed & 250 & 2.2 & 635000 & $2 \times 10^{-6}$ \\
\hline \multicolumn{5}{|c|}{ Carbon \#6: } \\
\hline Laboratory & 5 & 42 & 12864 & $1 \times 10^{-5}$ \\
\hline Laboratory & 10 & 21 & 10275 & $9 \times 10^{-5}$ \\
\hline Field Bed & 250 & 2 & 478000 & $6 \times 10^{-7}$ \\
\hline \multicolumn{5}{|c|}{ Pd \#1: } \\
\hline Laboratory & 50 & 4952 & 6482 & $3 \times 10^{-5}$ \\
\hline Laboratory & 150 & 1651 & 15994 & $3 \times 10^{-5}$ \\
\hline Field Bed & 3750 & 161 & 583000 & $<3 \times 10^{-9}$ \\
\hline
\end{tabular}

* 1 std. $\mathrm{ft} / \mathrm{hr}=0.29 \mathrm{Nm} / \mathrm{hr}$.

** Field samples were exposed to actual flue gas at Site 2; laboratory samples were exposed to synthesized Site 2 gas.

relative deactivation rates as a function of catalyst type and gas composition remains in question, and will be further evaluated.

\section{Catalyst Regeneration Tests}

Bench-scale tests were also carried out to investigate the possibility of regenerating catalysts. Previous results ${ }^{1,2}$ were promising, showing that catalysts deactivated during the first long-term test at Site 1 were effectively regenerated after being purged in $\mathrm{N}_{2}$ or $\mathrm{CO}_{2}$ at elevated temperatures. The catalysts, which had showed less than $30 \%$ mercury oxidation after 1100 hours of flue gas treatment, showed over $90 \%$ oxidation after regeneration. Results improved as the regeneration temperature was increased above $400^{\circ} \mathrm{F}\left(204^{\circ} \mathrm{C}\right)$. Higher levels of mercury were desorbed from the catalyst surfaces as the regeneration temperature was increased. The other species that desorbed from the catalyst surfaces on regeneration were selenium and sulfur.

Although lab results have been promising, it is not known what effect regeneration may have on the catalyst activity over an extended period of operation in flue gas compared to that of the 
virgin material. Some catalyst regeneration testing has been conducted on materials recovered from intermediate- and long-term testing at Site 2. These results are discussed below.

\section{Leaching of Acid from Samples Recovered from Site 2}

Samples recovered from the three-week screening test at Site 2 were tested to determine the amount of $\mathrm{SO}_{2}$ adsorbed while treating flue gas. Acid leaching tests were carried out by the following procedure. One gram of the catalyst/sand mixture was placed in $30 \mathrm{~mL}$ of water and stirred continuously for at least 30 minutes. Then, $\mathrm{pH}$ measurements were taken and used to calculate the amount of acid desorbed from the samples. The amount desorbed was assumed to represent all of the adsorbed acid species on each catalyst, and the desorbing acid was assumed to all be due to $\mathrm{SO}_{2}$ adsorption on the catalyst surface. These tests were repeated two to four times to improve accuracy. Figure 4-1 shows the average amount of $\mathrm{SO}_{2}$ adsorbed for each catalyst.

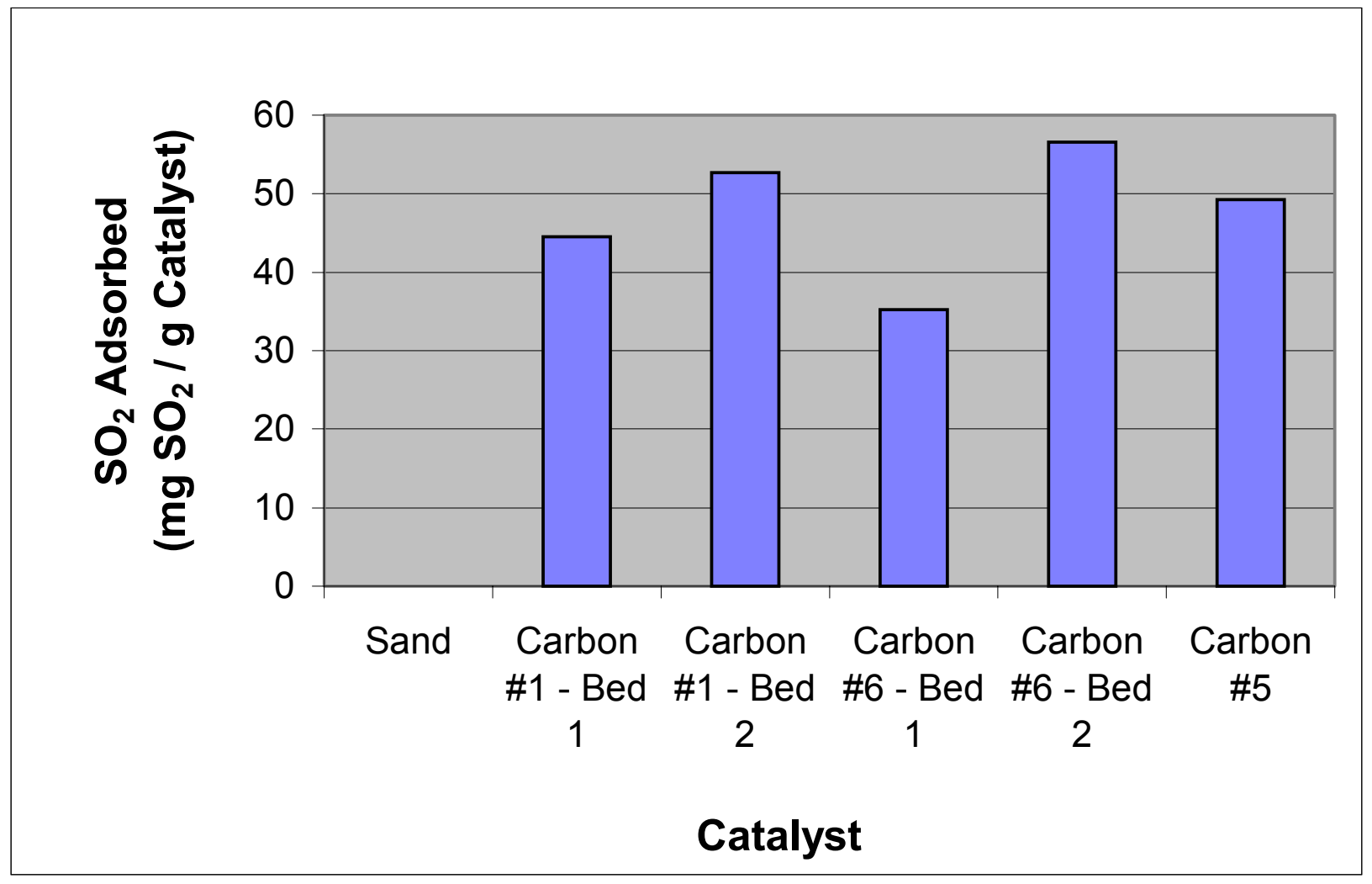

Figure 4-1

Acid Leachability for Catalysts from Intermediate - Length Test at Site 2

The sand blank showed negligible $\mathrm{SO}_{2}$ adsorption, and all catalyst samples showed $\mathrm{SO}_{2}$ adsorption levels within the same order of magnitude. The Carbon $\# 1 \mathrm{SO}_{2}$ concentrations are approximately one third to one half of the concentrations determined by conducting the same analysis on the Site 1 long-term samples. Less flue gas exposure and lower $\mathrm{SO}_{2}$ concentration in 
the Site 2 gas probably caused this difference; the typical uncontrolled $\mathrm{SO}_{2}$ concentrations in Site 1 and Site 2 flue gas are 1450 ppm and 300 ppm, respectively.

In the Site 1 leaching tests, Carbon \#1 desorbed much more $\mathrm{SO}_{2}$ than Carbon \#6, which is not the case for the Site 2 results. The tire-derived Carbon \#6 showed no apparent acidity after exposure to Site 1 flue gas, but significant acidity after the Site 2 exposure. Differences in exposure time, metal concentrations, and $\mathrm{SO}_{2}$ concentrations may cause the different $\mathrm{SO}_{2}$ adsorption behaviors seen at Sites 1 and 2. Carbon \#5 was not tested at Site 1, so no similar comparison can be made.

It is interesting that for both carbons in which two beds were tested in series, the second bed apparently adsorbed more $\mathrm{SO}_{2}$ (i.e., acidic species) than the first bed. Similar results were obtained for Carbon \#1 during long-term testing at Site 1. Although it is not known what causes this phenomenon, it suggests that $\mathrm{SO}_{2}$ adsorption in the first bed may be limited by the competing adsorption of other flue gas species at the catalyst surfaces. For Site 1, this competing species was thought to be selenium. No competing species has yet been identified for Site 2 .

\section{Regeneration of Catalysts from Site 2 Intermediate-length Tests}

While the long-term test at Site 2 was being conducted, we attempted to regenerate the Site 2, intermediate-length catalyst screening test samples (three-week screening set). These carbonbased samples were exposed to substantially less flue gas than the long-term test samples. Regeneration of these samples was expected to be similar to, if not easier than, regeneration of the long-term samples from Site 2.

These samples were first tested as recovered from the intermediate-length test, without any treatment steps. The samples were reacted with simulated flue gas (Site 2 conditions) to evaluate the respective mercury adsorption and oxidation abilities. Table 4-8 summarizes these results. In the table, "Reagent" values are measurements of fresh reagent performance tested in the laboratory; "Field Maximum" is the maximum percent oxidation measured at any time during field testing; "End of Field Test" measurements were taken in the field at the end of the threeweek test; and "Recovered Sample" measurements are laboratory results for the recovered field samples.

Only the two Carbon \#6 samples showed measurable mercury adsorption, albeit at very low levels. The maximum oxidation seen in the field tests for all samples was better or within $15 \%$ of the oxidation seen in "fresh" reagent tests in the laboratory. As the catalyst samples deactivated, these oxidation percentages declined, as was discussed in the previous section of this technical note. Interestingly, the recovered samples showed worse performance in simulated flue gas; all five samples showed less oxidation in the lab than in the field even though no treatment steps were taken and little additional (simulated) flue gas exposure occurred. Possible reasons for these differences may include variability in the oxidation percentage measurements or physical changes to the catalyst samples upon shut down of the unit, removal from the flue gas and subsequent exposure to air.

Several methods were attempted to regenerate the Carbon \#1, Bed 1 sample from the intermediate-length screening tests. Various temperatures and extended regeneration times were 
Table 4-8

Performance Comparison of Reagents and Recovered Field Samples

\begin{tabular}{|c|c|c|c|c|c|c|}
\hline \multirow[b]{2}{*}{ Sample } & \multicolumn{2}{|c|}{$\begin{array}{l}\text { Adsorption Capacity } \\
\text { ( } \mu \mathrm{g} \mathrm{Hg}^{\%} / \mathrm{g} \text { Catalyst) }\end{array}$} & \multicolumn{4}{|c|}{$\begin{array}{l}\text { Elemental Mercury Oxidation } \\
(\%)\end{array}$} \\
\hline & Reagent & $\begin{array}{l}\text { Recovered } \\
\text { Sample }\end{array}$ & Reagent & $\begin{array}{l}\text { Field } \\
\text { Maximum }\end{array}$ & $\begin{array}{l}\text { End of } \\
\text { Field Test }\end{array}$ & $\begin{array}{l}\text { Recovered } \\
\text { Sample }\end{array}$ \\
\hline Carbon \#1 - Bed 1 & 624 & 0 & 77 & 84 & 32 & 0 \\
\hline Carbon \#2 - Bed 2 & 624 & 0 & 77 & 89 & 74 & 37 \\
\hline Carbon \#5 & 5911 & 0 & 0 & 42 & 10 & 0 \\
\hline Carbon \#6 - Bed 1 & 401 & 20 & 100 & 87 & 76 & 24 \\
\hline Carbon \#6 - Bed 2 & 401 & 38 & 100 & 97 & 86 & 68 \\
\hline
\end{tabular}

tested. Sample washing was also evaluated by equilibrating samples in several different solutions. The "regenerated" samples were subsequently tested at Site 2 simulated conditions at $300^{\circ} \mathrm{F}\left(149^{\circ} \mathrm{C}\right)$; however, all samples showed negligible performance changes. Since no measurable performance improvements were noted, the test results are not presented here. Table 4-9 summarizes the conditions used to attempt regeneration.

Table 4-9

Conditions Tested to Regenerate the Carbon \#1 - Bed 1 Sample Recovered from the Site 2 Intermediate-length Screening Tests

\begin{tabular}{|c|c|c|c|}
\hline $\begin{array}{c}\text { Regeneration } \\
\text { Conditions }\end{array}$ & $\begin{array}{c}\text { Temperature } \\
{\left[{ }^{\circ} \mathrm{F}\left({ }^{\circ} \mathbf{C}\right)\right]}\end{array}$ & Duration (min) & Comments \\
\hline $\mathrm{CO}_{2}$ & $700(371)$ & 30 & $1 \mathrm{~L} / \mathrm{min}$ \\
\hline $\mathrm{CO}_{2}$ & $700(371)$ & 120 & $1 \mathrm{~L} / \mathrm{min}$ \\
\hline $\mathrm{CO}_{2}$ & $1000(538)$ & 120 & $1 \mathrm{~L} / \mathrm{min}$ \\
\hline $\mathrm{CO}_{2}$ & $1400(760)$ & 120 & $1 \mathrm{~L} / \mathrm{min}$ \\
\hline \begin{tabular}{c} 
Water Leaching \\
\hline $\begin{array}{c}0.1 \mathrm{M} \mathrm{NaOH} \\
\text { Leaching }\end{array}$
\end{tabular} & Ambient & $>24 \mathrm{hrs}$. & $\begin{array}{c}\text { Sample was centrifuged and decanted after } \\
\text { leaching. }\end{array}$ \\
\hline $\begin{array}{c}1.0 \mathrm{M} \mathrm{KCl} \\
\text { Leaching }\end{array}$ & Ambient & $>24 \mathrm{hrs}$. & $\begin{array}{c}\text { After leaching, sample was centrifuged, rinsed } \\
\text { in } \mathrm{H}_{2} 0, \text { centrifuged again and decanted. }\end{array}$ \\
\hline
\end{tabular}




\section{Regeneration of Catalysts from Site 2 Long-term Test}

Laboratory tests were also carried out with catalysts recovered from the Site 2 long-term exposure test. Initial tests were carried out to verify field mercury adsorption and oxidation results. Recovered samples were exposed to simulated flue gas at the conditions listed in Table 4-1. Mercury adsorption and oxidation were measured for each catalyst; these results are shown in Table 4-10. Recovered catalysts showed very low levels of mercury adsorption indicating that saturation had indeed occurred in the field test. The field sand "blank" was also tested and showed no mercury adsorption.

Table 4-10

Adsorption and Oxidation of Mercury by Recovered and Regenerated Catalysts

\begin{tabular}{|c|c|c|c|c|c|}
\hline \multirow[b]{2}{*}{ Sample } & \multicolumn{2}{|c|}{$\begin{array}{l}\text { Adsorption Capacity } \\
(\mu \mathrm{g} \mathrm{Hg} / \mathrm{g})\end{array}$} & \multicolumn{3}{|c|}{$\begin{array}{c}\text { Elemental Mercury Oxidation } \\
\left(\% \text { of Inlet } \mathrm{Hg}^{0}\right)\end{array}$} \\
\hline & $\begin{array}{l}\text { Recovered } \\
\text { Sample }\end{array}$ & $\begin{array}{l}\text { Regenerated } \\
\text { Sample }\end{array}$ & $\begin{array}{l}\text { End of Field } \\
\text { Test Sample }\end{array}$ & $\begin{array}{l}\text { Recovered } \\
\text { Sample }\end{array}$ & $\begin{array}{l}\text { Regenerated } \\
\text { Sample }\end{array}$ \\
\hline Carbon \#3 & 4 & 31 & 0 & 14 & 25 \\
\hline Carbon \#6 - Bed 1 & 0 & 45 & 40 & 40 & 94 \\
\hline Carbon \#6 - Bed 2 & 0 & 0 & 78 & 80 & 92 \\
\hline SBA \#5 & 5 & 433 & 87 & 98 & 82 \\
\hline $\mathrm{Pd} \# 1$ & 5 & 9 & 96 & 95 & 92 \\
\hline
\end{tabular}

Oxidation values in the field and lab corresponded within 14 percentage points, which is reasonable considering the potential for measurement error. Carbon \#3 remained virtually inactive, both beds of Carbon \#6 showed some remaining activity, and both Pd \#1 and SBA \#5 continued to show high oxidation activity. The Site 2 sand blank showed no mercury oxidation in the laboratory test.

Tests were then performed in which deactivated catalysts were purged with $\mathrm{CO}_{2}$ at elevated temperature in an attempt to regenerate the samples. A 10-gram fixed bed of each recovered catalyst/sand mixture was heated to $700^{\circ} \mathrm{F}\left(371^{\circ} \mathrm{C}\right)$; then purged with $\mathrm{CO}_{2}$ for 120 minutes. The "regenerated" samples were then tested in simulated flue gas to determine any effect on mercury adsorption capacity or oxidation performance.

The results in Table 4-10 show that regeneration improved the performance of the deactivated carbon samples. Carbon \#3 showed some improvement in adsorption capacity while mercury oxidation improved from 0 to $25 \%$. The adsorption capacity of the first bed of Carbon \#6 showed improvement while the second bed still showed no adsorption. Both beds showed very high oxidation levels ( $>90 \%$ ) after regeneration. These results suggest that the mechanisms of mercury adsorption and oxidation are not dependent upon each other for this sample. The two samples that showed good performance at the end of the Site 2 long-term (SBA \#5 and Pd \#1) 
showed no improvement in mercury oxidation upon regeneration. However, SBA \#5 showed a dramatic increase in adsorption capacity.

Initial regeneration testing has shown that most deactivated samples were easily regenerated in $\mathrm{CO}_{2}$. The extent of regeneration will likely vary from sample to sample. The ability to regenerate the oxidation catalysts should have dramatic implications on the overall cost of this process (see Section 5). Additional tests will be conducted to further evaluate the ability to regenerate the Site 2-treated catalysts.

\section{References}

1. Richardson, Dr. Carl F., et al. "Enhanced Control of Mercury by Wet FGD Systems." Presented at the EPRI-DOE-EPA Combined Utility Air Pollution Control Symposium: The MEGA Symposium, Atlanta, GA, August 16-20, 1999.

2. Enhanced Control of Mercury by Wet Flue Gas Desulfurization Systems - Site 1 Results, EPRI, Palo Alto, CA, and U.S. Department of Energy, Federal Energy Technology Center, Pittsburgh, PA, 1999, TE-113397. 


\section{5 \\ PRELIMINARY ECONOMICS FOR A CATALYTIC PROCESS}

Preliminary cost estimates have been made for the catalytic process under development, for a 400-MW power plant that has a conventional ESP for particulate control followed by a wet FGD system. The flue gas was assumed to have a total mercury content of $10 \mu \mathrm{g} / \mathrm{Nm}^{3}$, of which $25 \%$ is oxidized and $75 \%$ is in the elemental form. The catalyst is assumed to be $\mathrm{Pd} \# 1$ on a honeycomb support. The catalyst would be installed immediately downstream of the last field of the ESP, where the flue gas velocity would be about $5 \mathrm{ft} / \mathrm{sec}(1.5 \mathrm{~m} / \mathrm{s})$.

The catalyst life was projected to be three years. Pd \#1 saw little or no measurable loss of activity in over five months of testing at Site 2; it remains to be demonstrated what the actual life of this catalyst will be. Because it appeared that the catalyst loading on the honeycomb cores tested at Site 2 might be insufficient to result in high oxidation efficiency, a three-times higher palladium loading was assumed for this estimate. Although we do not yet have reliable information about the relationship between area velocity and elemental mercury oxidation percentage, for these preliminary estimates we assumed that a 6 -inch $(15-\mathrm{cm})$ catalyst depth would result in greater than $90 \%$ oxidation and that a 4 -inch $(10-\mathrm{cm})$ catalyst depth would result in $80 \%$. These catalyst depths correspond with area velocities of 72 and 108 standard $\mathrm{ft} / \mathrm{hr}$, respectively (21 and $31 \mathrm{Nm} / \mathrm{hr}$ ).

The projected costs for this process were compared to cost estimates for activated carbon injection for mercury control, as presented in a previous EPRI-sponsored paper ${ }^{1}$. In that paper, it was determined that it was more cost effective to retrofit a high-ratio fabric filter downstream of the ESP (i.e., the EPRI COHPAC configuration) when injecting activated carbon for mercury control. Their estimates showed that prohibitively large quantities of carbon were required to achieve high mercury removal efficiency with only the ESP as a gas-solid contactor. That paper presented cost estimates for an $80 \%$ mercury removal level, but we used data and cost equations presented in the paper to project costs for a 90\% removal level with carbon injection. We also used the same economic factors and plant descriptions used in the EPRI paper in developing preliminary estimates for the catalytic process. These estimates for capital, operating and maintenance (O\&M) and levelized costs are compared for $80 \%$ and $90 \%$ overall mercury removal levels in Table 5-1.

The mercury control levels for the catalytic process in Table 5-1 are based on the assumption that the wet FGD system will achieve 95\% removal of the oxidized mercury in the FGD inlet flue gas, and no removal of elemental mercury. Note that the EPRI paper did not consider the whether the hypothetical power plant had a wet FGD system or any contribution from that FGD 
Table 5-1

Preliminary Cost Estimates for the Catalytic Process for Enhancing Mercury Removal by a Wet FGD System, Compared to Activated Carbon Injection

\begin{tabular}{|c|c|c|c|c|}
\hline Mercury Removal Process & \multicolumn{2}{|c|}{ Catalyst } & \multicolumn{2}{c|}{ Carbon Injection/COHPAC } \\
\hline Overall Hg Removal (\%) & 80 & 90 & 80 & 90 \\
\hline $\begin{array}{c}\text { Total Capital Requirement (\$1000; } \\
\text { excludes catalyst costs) }\end{array}$ & $\$ 1,949$ & $\$ 1,949$ & $\$ 15,877$ & $\$ 15,941$ \\
\hline $\begin{array}{c}\text { Levelized Capital Requirement } \\
(\$ 1000 / y r)\end{array}$ & $\$ 199$ & $\$ 199$ & $\$ 1,619$ & $\$ 1,626$ \\
\hline Total O\&M Cost (\$1000/yr) & $\$ 1,418$ & $\$ 2,125$ & $\$ 1,858$ & $\$ 2,661$ \\
\hline Levelized O\&M Cost (\$1000/yr) & $\$ 2,126$ & $\$ 3,188$ & $\$ 2,787$ & $\$ 3,992$ \\
\hline $\begin{array}{c}\text { Total Levelized Cost (\$1000/yr) } \\
\text { Percent reduction (relative to carbon } \\
\text { injection/COHPAC) }\end{array}$ & $47 \%$ & $40 \%$ & $\$ 4,406$ & $\$ 5,618$ \\
\hline
\end{tabular}

system to mercury removal. However, we assume that downstream of the carbon injection system there would be essentially no oxidized mercury remaining; we assume that the remaining, unremoved mercury would be all elemental mercury. This should be a good assumption since oxidized mercury is more readily removed by carbon injection than is elemental mercury. In this case the mercury removal by a wet FGD system downstream of a carbon injection system would be zero.

Also, note that the capital cost estimates for the catalytic process do not include the cost of the initial catalyst charge. The catalyst cost is instead treated as an O\&M expense, since it must be replaced every three years.

The preliminary results in Table 14 show that the catalytic process holds some promise for lowering future mercury control costs for power plants with existing FGD systems. Future process development work is needed to substantiate and refine the assumptions made to develop these cost estimates. Longer catalyst life will tend to drive the costs down. Also, less expensive catalysts, such as fly ash based catalysts, will tend to lower costs.

\section{References}

1. Meserole, F.B., et al. "Estimating Electric Utility Mercury Control Costs Using Sorbent Injection." Presented at the EPRI-DOE-EPA Combined Utility Air Pollution Control Symposium: The MEGA Symposium, Atlanta, GA, August 16-20, 1999. 


\section{6 \\ CONCLUSIONS}

\section{Long-term Test Results}

Field testing at Site 2, fired with a Powder River Basin subbituminous coal, found substantial concentrations of elemental mercury in the flue gas $\left(\sim 8\right.$ to $\left.9 \mu \mathrm{g} / \mathrm{Nm}^{3}\right)$ and relatively low concentrations of $\mathrm{SO}_{2}, \mathrm{SO}_{3}, \mathrm{HCl}$ and $\mathrm{NO}_{\mathrm{X}}$. At these flue gas conditions, long-term (five-month) sand bed reactor tests showed that one catalyst, $\mathrm{Pd} \# 1$, continued to oxidize $96 \%$ of the inlet elemental mercury. It is not possible to predict the life of the $\mathrm{Pd} \# 1$ catalyst based on these results, as the observed drop in activity over the five-month period was small relative to experimental error. These results, therefore, cannot be extrapolated to predict loss of activity over longer periods with any certainty.

The fly-ash-based catalyst, SBA \#5, continued to achieve $87 \%$ oxidation, and two beds of Carbon \#6 in series achieved 78\% oxidation at the end of the five-month test. Both could be viable candidate catalysts for these flue gas conditions, and should be less expensive to manufacture than Pd \#1. The other catalyst, Carbon \#3, lost virtually all activity towards the oxidation of elemental mercury over this period, and is not a candidate catalyst material for this flue gas.

These results identified $\mathrm{Pd} \# 1$ as the most attractive oxidation catalyst for this flue gas with respect to catalyst life. The fly-ash-based SBA \#5 could offer a lower-cost alternative, although a method needs to be developed to prepare the fly-ash-based material in a commercial catalyst form. Carbon \#6 could also be a candidate catalyst, if it can be regenerated cost effectively.

\section{Commercial Catalyst Forms}

Samples of Pd \#1 were tested in relatively short-term tests (two to six weeks) tests in two commercially-viable forms: pellet and "honeycomb" configurations. The pellet form showed high oxidation activity at area velocities 5 to 10 times that of commercial SCR catalysts, suggesting that relatively small reactors could be employed for a catalytic mercury oxidation process. Results with a honeycomb catalyst showed lower oxidation activity when compared to the pellet form at similar area velocities. The amount of palladium on the honeycomb surface and the rate of diffusion of mercury from the flue gas to its surface are potential causes of the lower performance of the honeycomb configuration. However, it is still likely that high mercury oxidation percentages can be achieved with $\mathrm{Pd} \# 1$ in a honeycomb configuration with reactor volumes considerably smaller than what is required for SCR applications. 


\section{Laboratory Test Results}

Laboratory tests indicate that for the gas composition at Site 2, both $\mathrm{HCl}$ and $\mathrm{NO}_{\mathrm{X}}$ play an important role in mercury oxidation, even when present at low concentrations (e.g., 1 ppm for $\mathrm{HCl})$. These results confirm the need to include these species in laboratory simulation gases. For most materials, the laboratory apparatus proved to be an effective tool at identifying catalyst materials that were active in the actual Site 2 flue gas conditions. However, the effectiveness of accelerated catalyst deactivation tests in the laboratory for predicting long-term catalyst activity in the field remains in question.

Laboratory tests to regenerate spent catalyst materials from the long-term test at Site 2 showed that activity could be restored with relatively short-term (120-minute) exposure to a $\mathrm{CO}_{2}$ environment at $700^{\circ} \mathrm{F}\left(371^{\circ} \mathrm{C}\right)$. These results suggest that catalyst regeneration could be an alternative to replacement as catalyst activity declines. However, the activity versus time exposed to flue gas for the regenerated material needs to be determined relative to that of the virgin material.

\section{Preliminary Economics}

Preliminary economics for the catalytic process applied to a power plant with an existing ESP particulate collector and an FGD system, based on Site 2 results for Pd \#1, show that the catalytic process could be less costly than carbon injection for achieving $80 \%$ to $90 \%$ overall mercury control. The economics are based on using a honeycomb catalyst configuration, and the mercury removal percentages are based on mercury levels in the ESP outlet flue gas. The economics for the catalytic process using $\mathrm{Pd} \# 1$ as the catalyst on a honeycomb structure are very sensitive to catalyst life, honeycomb surface area, and the loading of $\mathrm{Pd} \# 1$ required on the surface.

\section{Future Testing}

The results from Site 2 are very promising with respect to the applicability of a catalytic process to enhance mercury removal by plants that have an existing FGD system and that fire a subbituminous coal. Testing at Site 3, which will fire a high-sulfur, bituminous coal, should continue as planned. Results from Site 3 will determine whether a catalytic process shows promise for the larger population of bituminous-coal-fired power plants that have FGD systems.

As mentioned above, the economics for the catalytic process using Pd \#1 as the catalyst on a honeycomb structure are very sensitive to catalyst life, honeycomb surface area, and the loading of $\mathrm{Pd} \# 1$ required on the surface. A future project should determine the honeycomb surface area and loading of $\mathrm{Pd} \# 1$ required to achieve high mercury oxidation percentages, and should determine the activity of $\mathrm{Pd} \# 1$ in a honeycomb configuration over periods of one year or greater. This project should also evaluate lower-cost materials such as fly-ash-based SBA \#5 in commercial catalyst configurations. 
A future project should also further investigate catalyst regeneration as a means of lowering the potential cost of a catalytic process. In particular, the activity of regenerated material over time should be evaluated relative to that of virgin material. The potential for in-situ regeneration should be investigated for technical and economic feasibility. 


\section{ACKNOWLEDGEMENTS}

We would like to thank the Site 2 utility for allowing us to test at their power plant and their staff for the support they have provided. We would also like to thank the U.S. Department of Energy National Energy Technology Laboratory and EPRI for their co-funding of this project and for their technical input and guidance. 